\title{
Esterase production by Aureobasidium pullulans URM 7059 in stirred tank and airlift bioreactors using residual biodiesel glycerol as substrate
}

\author{
Dayana P. Meneses $^{\mathrm{a}}$, Livia Maria N. Paixão ${ }^{\mathrm{b}}$, Thatyane V. Fonteles ${ }^{\mathrm{b}}$, Eduardo J. Gudiña ${ }^{\mathrm{c}}$, Ligia \\ R. Rodrigues ${ }^{c}$, Fabiano A.N. Fernandes ${ }^{a}$, Sueli Rodrigues ${ }^{\text {b,* }}$ \\ ${ }^{a}$ Chemical Engineering Department, Federal University of Ceará, Campus do Pici Bloco 709, 60440-900, Fortaleza, Brazil \\ ${ }^{\mathrm{b}}$ Food Engineering Department, Federal University of Ceará, Campus do Pici Bloco 851, 60440-900, Fortaleza, Brazil \\ ${ }^{\mathrm{c}}$ CEB - Centre of Biological Engineering, University of Minho, Campus de Gualtar, 4710-057, Braga, Portugal
}

\section{A R T I C L E I N F O}

\section{Keywords:}

Esterase

Aureobasidium pullulans URM 7059

Airlift reactor

Biodegradation

\begin{abstract}
A B S T R A C T
Aureobasidium pullulans URM 7059 produced esterase using residual glycerol from biodiesel as the sole carbon source. The culture medium containing residual glycerol $(0.1 \% \mathrm{v} / \mathrm{v}),\left(\mathrm{NH}_{4}\right)_{2} \mathrm{SO}_{4}(4 \mathrm{~g} / \mathrm{L})$, and yeast extract $(8 \mathrm{~g} /$ $\mathrm{L})$ resulted in the highest esterase production using shake-flasks. The enzyme exhibited a molar mass of $50 \mathrm{kDa}$ and was stable at neutral $\mathrm{pH}$ and temperatures below $30{ }^{\circ} \mathrm{C}$. The cations $\mathrm{Cu}^{2+}$ and $\mathrm{Al}^{3+}$ did not affect the esterase activity, while $\mathrm{Ca}^{2+}$ promoted the highest activity loss. The enzyme kinetic parameters were determined using different substrates ( $p$-nitrophenylcaprylate and p-nitrophenylbutyrate). $\mathrm{K}_{\mathrm{m}}$ and $\mathrm{V}_{\max }$ were $1.4 \mathrm{mM}$ and $218 \mu \mathrm{mol}$ $\mathrm{min}^{-1}$ for $p$-NPC, and $1.55 \mathrm{mM}$ and $76.7 \mu \mathrm{mol} \mathrm{min}^{-1}$ for $p$-NPB. The esterase production was further evaluated using stirred tank and 2-L airlift bioreactors. The airlift reactor operating at the highest air flow rate $(8 \mathrm{~L} / \mathrm{min})$ increased the enzyme productivity 3-fold compared to the shake-flasks experiments. However, the crude enzymatic extract showed 3 active protein bands by zymography with molecular masses of $172 \mathrm{kDa}, 66 \mathrm{kDa}$, and 40 $\mathrm{kDa}$ approximately, suggesting that the pattern of enzyme production changed due to aeration. The crude enzyme degraded the MACO-Sty biopolymer in 14 days, being stable in a wide range of $\mathrm{pH}(7.0-9.0)$ and temperatures $\left(40{ }^{\circ} \mathrm{C}-80{ }^{\circ} \mathrm{C}\right)$. The results suggest that this enzyme is a promising catalyst in remediation processes.
\end{abstract}

\section{Introduction}

Esterases are carboxyl ester hydrolases that catalyze the cleavage of triglyceride ester bonds. They have a high affinity for substrates with low hydrophobicity. Thus, their enzymatic activity relies on watersoluble substrates [1-3]. As such, esterases catalyze the hydrolysis of short-chain water-soluble fatty acid triglycerides $(<10$ carbon atoms), while lipases catalyze the hydrolysis of long-chain fatty acids $(\geq 10$ carbon atoms). The catalytic triad formed by Ser, His, and Asp are the bases of esterase's activity with serine incorporated into the GI-X-Ser-X-Gly sequence at the active site [4-6].

The global enzymes are US\$ 5 billion markets, with lipases and esterases accounting for $10 \%$. The lipases and esterases market should increase by up to $8 \%$ in 2020, reaching approximately US\$ 7 billion [7]. The worldwide leading biotech enzyme producer companies are Fluka, Novozymes, and Sigma-Aldrich Ltd. [8,9]. Exploring the global microbial biodiversity opens several possibilities to discover new enzymes with biochemical advantages over the existing ones. Indeed, diverse regiospecificity and regioselectivity are potentially useful for many industrial applications $[10,11]$. Enzymatic depolymerization of polyesters throughout ester bonds cleavage, soil and wastewater bioremediation, pesticides removal, aroma compounds, and optically pure chiral drugs synthesis are the most common esterase applications [12,13].

Esterases are produced by bacteria, fungi, and yeasts $[14,15]$. Examples of esterase producers include Bacillus cereus (1.79 U/mg) [16], Staphylococcus xylosus (11.32 U/mg) [17], Penicillium purpurogenum [18], Geobacillus thermodenitrificans (9.0 U/mg) [19] and Glaciozyma antartica $(1.15 \mathrm{U} / \mathrm{mg})$ [20]. Although lipolytic enzymes' production is reported for several yeasts and bacteria [21-27], Aureobasidium pullulans, an yeast like strain, were so far only described as a pullulan producer.

Microbial enzymes are of industrial relevance given their applications in synthesizing valuable compounds, such as pharmaceuticals, food, and biofuels [23]. The development of new production routes

\footnotetext{
* Corresponding author.

E-mail address: sueli@ufc.br (S. Rodrigues).
} 


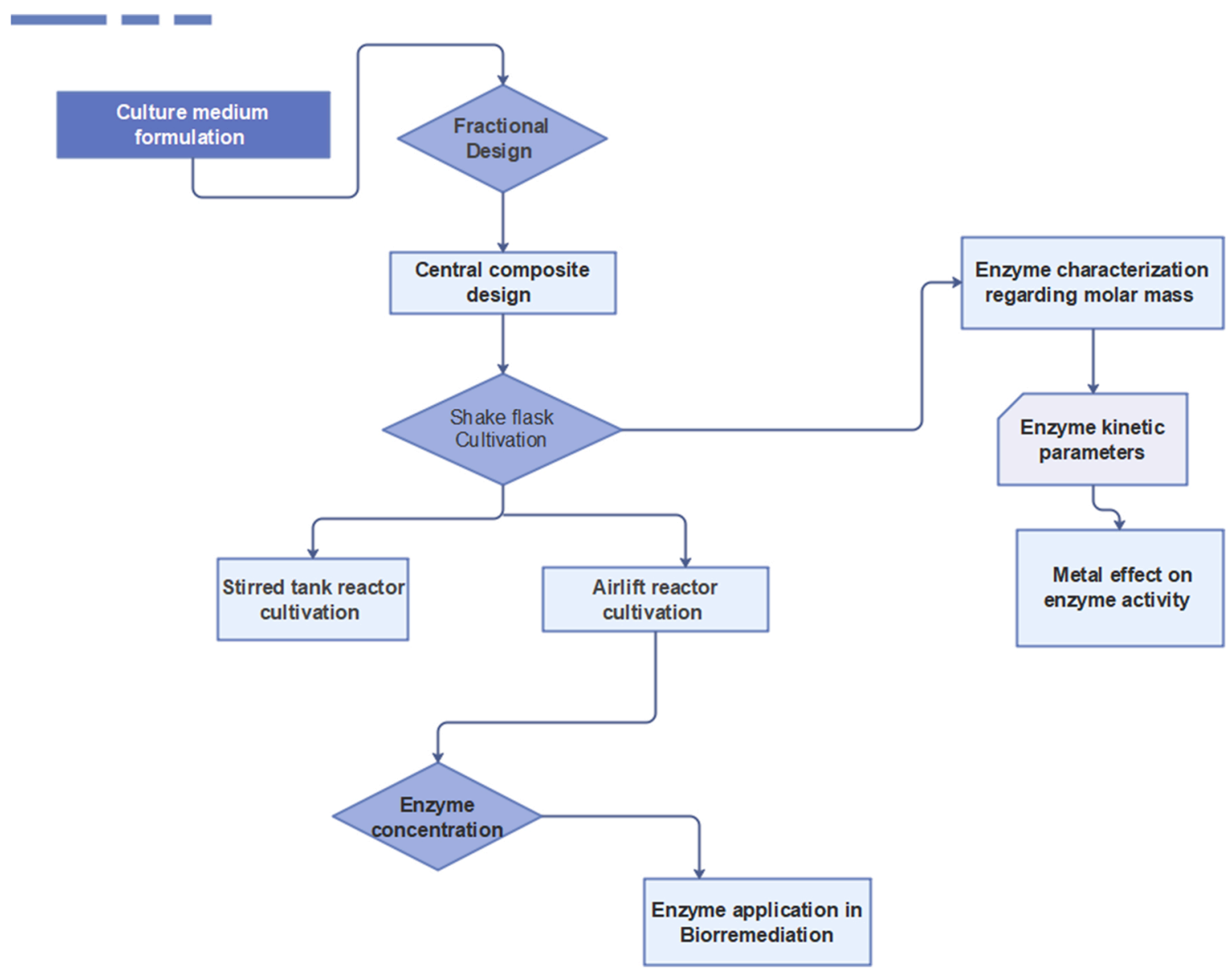

Fig. 1. Flow chart of esterase production by Aerobasidium pullulans URM 7059.

using industrial wastes as the source of nutrients for enzyme production is an interesting approach towards costs reduction and process sustainability [24]. Different carbons sources have been assessed, such as glucose [25], beet pulp [18], olive oil [26], and palm oil [28]. Glycerol is a promising carbon source due to its natural degradation into different metabolic intermediates during fermentation. However, few microorganisms metabolize glycerol as the sole carbon source. The glycerol metabolism by A. pullulans includes the degradation and the uptake of glycerol into the cell. The glycerol uptake by Aureobasidium pullulans is by active transport. The glycerol is catabolized through the $\mathrm{NAD}^{+}$dependent glycerol-3-phosphate dehydrogenase pathway, with a mitochondrial glycerol-3-phosphate dehydrogenase and glycerol kinase [29].

Yarrowia lipolytica intracellular lipase production. Previous studies reported the efficiency of biomolecules synthesis using raw residual glycerol as carbon sources such as the Yarrowia lipolytica intracellular lipase production [28]; the lipid production [30], and the biosurfactants production by Bacillus subtilis [31]. However, the use of glycerol as the carbon source for enzyme production is scarce. To our knowledge, this is the first study using glycerol for esterase production.

In the last years, the price of glycerol decreased by about $20 \%$, highlighting its potential use in the production of high-value products, such as esterases [30]. The carbon source plays a critical role in culture medium costs, particularly at an industrial scale. Because of that, the limiting substrate is usually the carbon source. The use of residual glycerol for esterase production has not yet been described. The potential use of a readily available and cheap substrate substantially decreases the production costs.

Another critical element in enzymes' production is the type of bioreactor used, being the stirred tank (STR), bubble column reactors, and airlift reactor ALR [32] the most commonly used. Relevant parameters include mixing and aeration rate due to their impact on mass transfer, biomass production, dissolved oxygen, and product yields. In the STR reactor, the impellers promote medium homogenization. The agitation influences the process yield production due to the agitation power and, consequently, the nutrient mass transfer, biomass growth, and cellular metabolism [33]. Airlift reactors, due to their design, provide a different mixing and higher mass transfer coefficients than the STR. Airlift reactors are better for aerobic microorganisms due to a better-dissolved oxygen rate comparing to STR [34]. Besides the reactor, the culture medium composition is particularly important to ensure a higher yield and lower production costs.

In the present study, A. pullulans URM 7059, a strain isolated by our group and not previously described as an esterase producer, was cultivated in submerged fermentation using residual biodiesel glycerol as the sole carbon source. In the present study, the aeration effect on the esterase production was evaluated using two different bioreactor types (Stirred Tank (STR) and Airlift (ALR) reactors). The produced esterase was partially purified and characterized, and further applied in a biopolymer degradation assay. Thus, the study covers a complete bioprocess design from the culture medium formulation (shake-flasks) to product application as summarized in Fig. 1. 


\section{Materials and methods}

\subsection{Microorganism}

Aureobasidum pullulans URM 7059 was isolated from the cashew (Anacardium occidentale L.) apple peduncle by traditional plate culture. The pure culture was then molecularly identified by 16S rRNA sequencing. The strain was deposited at URM collection at the Federal University of Pernambuco (UFPE, Brazil) with the catalog number URM 7059. The strain was kept at $-20{ }^{\circ} \mathrm{C}$ in Yeast Extract Peptone-Dextrose (YPD) medium supplemented with $20 \%(\mathrm{w} / \mathrm{w})$ of glycerol in the laboratory. The inoculums were prepared in $250 \mathrm{~mL}$ Erlenmeyer flasks containing $100 \mathrm{~mL}$ of YPD broth (peptone $20 \mathrm{~g} / \mathrm{L}$; yeast extract $10 \mathrm{~g} / \mathrm{L}$ and glucose $20 \mathrm{~g} / \mathrm{L} ; \mathrm{pH} 6.5$ and were further incubated in an orbital shaker at $28{ }^{\circ} \mathrm{C}$ and $200 \mathrm{rpm}$ for $12 \mathrm{~h}$.

\subsection{Culture medium composition}

Firstly, the glucose was removed from the original medium composition keeping the residual glycerol (Brasil Ecodiesel, Iraquara - Bahia/ Brazil) as the sole carbon source, and using constant concentrations of Tween $80(0.4 \% \mathrm{w} / \mathrm{w})$ and $\mathrm{KH}_{2} \mathrm{PO}_{4}(1 \mathrm{~g} / \mathrm{L})$ at initial $\mathrm{pH}$ 5.5. The glycerol contained about $77 \%$ of glycerin and some free fatty acids quantified as the saponification index $(4.83 \mathrm{mg} \mathrm{KOH} / \mathrm{g})$. The full residue characterization provided by Brasil Ecodiesel is presented in the Supplementary Material (Table S1). A fractional factorial design $2^{3-1}$ (Table 2) with three repetitions at the central point, accounting for seven trials, was performed to evaluate the effect of each independent variable (glycerol, yeast extract, and $\left(\mathrm{NH}_{4}\right)_{2} \mathrm{SO}_{4}$ ) on the production of esterase. The response variable was the enzyme activity. The software Statistica v.13.0 was used to generate the experimental design and analyze the data.

The best concentration of CSL (corn steep liquor) and yeast extract as nitrogen source was determined through a face-centered Central Composite Design (CCD). The concentrations of glycerol $(0.1 \% \mathrm{v} / \mathrm{v})$ and ammonium sulfate $(4 \mathrm{~g} / \mathrm{L})$ were kept constant. CSL, provided by Companhia Portuguesa de Amidos (COPAM-SA, Portugal), contained $75 \mathrm{~g} / \mathrm{L}$ of carbohydrates and $5 \mathrm{~g} / \mathrm{L}$ of protein. The total sugars and total soluble protein concentrations present in CLS were determined using the phenol-sulfuric [35] and Lowry [36] methods. The experiment was conducted with two variables at two levels $\left(2^{2}\right)$, including four trials at the axial conditions and three replicates at the central point, totalizing eleven trials (Table 3 ). The response variable was the enzyme activity values using two substrates, $p$-nitrophenylbutyrate ( $p$-NPB) and $p$-nitrophenylcaprylate ( $p$-NPC). Again, the software Statistica v.13.0 was used for experimental planning and data analysis.

\subsection{Esterase production}

The yeast $A$. pullulans URM 7059 was inoculated in culture medium containing: yeast extract $(8 \mathrm{~g} / \mathrm{L}),\left(\mathrm{NH}_{4}\right)_{2} \mathrm{SO}_{4}(4 \mathrm{~g} / \mathrm{L})$, residual glycerol (1 $\% \mathrm{v} / \mathrm{v}), \mathrm{KH}_{2} \mathrm{PO}_{4}(1 \mathrm{~g} / \mathrm{L})$ and Tween $80(0.4 \% \mathrm{v} / \mathrm{v})$. The experiments were carried out in a rotatory shaker using $500 \mathrm{~mL}$ Erlenmeyer flasks containing $200 \mathrm{~mL}$ of medium and incubated at $28^{\circ} \mathrm{C}$ (A. pullulans is a mesophilic strain) and $200 \mathrm{rpm}$ for $48 \mathrm{~h}$ to allow the glycerol depletion. The inoculum concentration was standardized and adjusted to $1 \times 10^{7}$ cells $/ \mathrm{mL}$. Samples were collected at regular time intervals to determine biomass concentration and were further centrifuged $(2700 \mathrm{~g}, 15 \mathrm{~min}, 4$ ${ }^{\circ} \mathrm{C}$ ) to determine the supernatant's enzyme activity. The initial $\mathrm{pH}$ was 5.5 , and the final $\mathrm{pH}$ was $7.0 \pm 0.3$.

Regarding the cultivation in bioreactors stirred thank (STR) and airlift reactor (ALR) were evaluated. Firstly, the yeast A. pullulans URM 7059 was inoculated in the culture medium $(800 \mathrm{~mL})$ and cultivated in a stirred tank reactor (Tecnal, Tecbio model, with a maximal working volume of $1.0 \mathrm{~L})$, at controlled temperature $\left(28^{\circ} \mathrm{C}\right), 200 \mathrm{rpm}$, initial $\mathrm{pH}$ 5.5 and aeration rate of $2 \mathrm{~L} / \mathrm{min}$ without $\mathrm{pH}$ control. The reactor was equipped with a double impeller turbine model Rushton (DRT), with a diameter of $0.035 \mathrm{~m}$, and the culture medium volume used was enough to cover both impellers. The reactor tank diameter was $0.09 \mathrm{~m}$, and the liquid vessel height was $0.15 \mathrm{~m}$. The inoculum concentration was standardized and adjusted to $2 \times 10^{8}$ cells $/ \mathrm{mL}$, using a Neubauer improved cell chamber (Marienfeld $\mathrm{GmbH}$, Germany). Samples were collected at regular time intervals and centrifuged $\left(2700 \mathrm{~g}, 15 \mathrm{~min}, 4^{\circ} \mathrm{C}\right)$ to obtain the biomass and cell-free supernatant for further enzyme activity determination.

The enzyme production by A. pullulans URM 7059 was also evaluated using an airlift reactor (Tecnal, BIO-TEC-FLEX, with a working volume of $2.0 \mathrm{~L}$ ) at the same initial $\mathrm{pH} 5.5$, temperature, and initial inoculum as used in the stirred tank. The airlift reactor diameter was $0.095 \mathrm{~m}$ with the liquid height at $0.30 \mathrm{~m}$ and a $0.22 \mathrm{~m}$ high riser. The riser internal area was (internal area $\left(\mathrm{A}_{\mathrm{I}}\right)=0.0121 \mathrm{~m}^{2}$ and external area $\left(\mathrm{A}_{\mathrm{e}}\right)=$ $0.0285 \mathrm{~m}^{2}$. Different flow rates were evaluated in the airlift experiments covering the whole equipment operating range $(2,4,6$, and $8 \mathrm{~L} / \mathrm{min})$. Dissolved oxygen and $\mathrm{pH}$ were monitored throughout the fermentation. However, $\mathrm{pH}$ control was found to be deleterious for the enzyme, so the $\mathrm{pH}$ value was only monitored but not controlled in both studied reactors. The $\mathrm{pH}$ increased from 5.5 to $7.0 \pm 0.3$ at the end of the production process in all assays.

\subsection{Esterase activity}

The esterase activity in the cell-free supernatants was determined using $p$-nitrophenol butirate ( $p$-NPB - 4 carbons fatty acid chain) and $p$ nitrophenol caprilate ( $p$-NPC - 8 carbons fatty acid chain) as substrate. Those substrates are water-soluble and present a short chain (less than 10 carbon units), making them suitable for esterase activity determination. One unit of enzyme activity (U) is the amount of enzyme that hydrolyzes $1 \mu \mathrm{mol}$ of $p$-nitrophenol per min. The substrate containing $1.12 \mathrm{mM}$ of $p$-NPB or $p$-NPC was prepared in PBS $(50 \mathrm{Mm}) \mathrm{pH} 7.0$, containing $4 \%(\mathrm{v} / \mathrm{v})$ of Triton X-100. An aliquot of $20 \mu \mathrm{L}$ of the sample (cell-free supernatant) and $980 \mu \mathrm{L}$ of the substrate was incubated at 40 ${ }^{\circ} \mathrm{C}\left(p\right.$-NPC) and $50{ }^{\circ} \mathrm{C}$ ( $p$-NPB) for 15 min to determine the enzyme activity. After that, $2 \mathrm{~mL}$ of acetone was added to stop the reaction, and the absorbance was measured at $405 \mathrm{~nm}$ [37].

\subsection{Optimum $\mathrm{pH}$ and temperature for enzyme activity}

These assays were carried out for the $\mathrm{pH}$ range from 5.0 to 9.0, keeping the temperature constant at $30{ }^{\circ} \mathrm{C}$ and then, for several temperatures $\left(30,37,40,50\right.$, and $\left.60^{\circ} \mathrm{C}\right)$, maintaining a constant $\mathrm{pH}$ value (pH 7.0). To determine the optimal $\mathrm{pH}$, several buffer solutions (at 0.025 $\mathrm{M}$ concentration) were used, namely sodium acetate buffer, $\mathrm{pH}$ 5.0-6.0; sodium phosphate buffer, $\mathrm{pH}$ 7.0-8.0; and glycine buffer, $\mathrm{pH} 9.0-10.0$. The enzymatic activities were determined, as described in section 2.4.

\subsection{Glycerol consumption}

The glycerol consumption was determined by High-Pressure Liquid Chromatography (HPLC) using an Agilent 1260 infinity equipment (Wilmington, Delaware, USA), equipped with a refractive index (RI) and UV-vis detector. An Aminex HPX column 87H (Bio-Rad Laboratories Inc., USA) at $60{ }^{\circ} \mathrm{C}$ and $0.005 \mathrm{~mol} / \mathrm{L} \mathrm{H}_{2} \mathrm{SO}_{4}$ solution at $0.7 \mathrm{~mL} / \mathrm{min}$ as mobile phase were used. Concentrations were determined using a calibration curve with standard glycerol concentrations ranging between $1-20 \mathrm{~g} / \mathrm{L}$. The samples were filtered in a nylon membrane before injection and detected by a refraction index (RI) detector at $35^{\circ} \mathrm{C}$.

\subsection{Esterase partial purification and concentration}

\subsubsection{Protein precipitation}

The esterase produced in shake-flasks was precipitated from the cellfree culture broth with polyethylene glycol (PEG) at $50 \%(\mathrm{w} / \mathrm{v})$. The 
PEG solutions were prepared using PEG 1500, 4000 and 6000, and added to the crude enzyme at a $1: 1(\mathrm{v} / \mathrm{v})$ ratio at $25{ }^{\circ} \mathrm{C}$, with slow agitation. After homogenization, the mixture was centrifuged $(16,000 \mathrm{~g}$, for $10 \mathrm{~min}$ at $\left.4{ }^{\circ} \mathrm{C}\right)$, and the precipitate was dissolved in $50 \mathrm{mM} \mathrm{PBS}(\mathrm{pH}$ 7.0) [38].

Moreover, esterase precipitation from the cell-free culture broth using ammonium sulfate at the saturation concentration range $30-90 \%$ $(\mathrm{w} / \mathrm{v})$ was also done. The salt was dissolved directly in the cell-free culture broth, and the mixture was left to rest for $4 \mathrm{~h}$ at room temperature $\left(25^{\circ} \mathrm{C}\right)$. The protein pellet was collected after centrifugation $\left(10,000 \mathrm{~g}\right.$, for $30 \mathrm{~min}$ at $\left.4{ }^{\circ} \mathrm{C}\right)$ and resuspended in $50 \mathrm{mM}$ PBS, pH 7.0. Then, these solutions were dialyzed using a cellulose acetate membrane (12 kDa cut-off) against the same buffer for $4 \mathrm{~h}$ (room temperature) [38] The total protein content was determined using the Bradford method [39].

\subsubsection{Enzyme membrane concentration}

Although precipitation is an excellent approach to characterize an enzyme, this technique is costly and time-consuming if industrial applications are envisaged. Due to the higher enzyme production in the airlift reactor $(2 \mathrm{~L} / \mathrm{min})$, a large volume $(8.5 \mathrm{~L})$ of crude esterase was produced from 5 batches carried out at the best operating condition regarding air flow rate in the ALR $(8 \mathrm{~L} / \mathrm{min})$. After each airlift batch, the crude enzyme, free of cells, was frozen at $-20^{\circ} \mathrm{C}$. The total volume was concentrated to $250 \mathrm{~mL}$ by ultrafiltration with a $10 \mathrm{kDa}$ cut-off membrane at $25{ }^{\circ} \mathrm{C}$. The concentrate was precipitated with ammonium sulfate $(30$ and $90 \% \mathrm{w} / \mathrm{v})$ at $25{ }^{\circ} \mathrm{C}$. The precipitated protein collected after centrifugation $\left(10,000 \mathrm{~g}\right.$, for $30 \mathrm{~min}$ at $\left.4{ }^{\circ} \mathrm{C}\right)$ was dissolved in $50 \mathrm{mM}$ PBS, $\mathrm{pH}$ 7.0. Then, the sample was dialyzed using a cellulose acetate membrane (12 kDa cut-off) against the same buffer for $4 \mathrm{~h}$ at $25{ }^{\circ} \mathrm{C}$. This supernatant was also precipitated using acetone at $0{ }^{\circ} \mathrm{C}$. After the acetone evaporation, the protein pellet was resuspended in Tris $0.1 \mathrm{M}$ ( $\mathrm{pH}$ 8.0). The total protein content was determined using the Bradford method [39], and esterase activity was determined as previously described.

\subsubsection{Esterase molar mass}

The esterase molar mass was determined by SDS-PAGE using a 12.5 $\%$ sodium dodecyl sulfate polyacrylamide gel electrophoresis (SDSPAGE) at under denaturing conditions at $\mathrm{pH} 8.8$ and $4 \%$ stacking gel (pH 6.8) [40]. Electrophoresis was performed at $120 \mathrm{mV}$ and $30 \mathrm{~mA}$ using a MiniV equipment (Ge Healthy Care). Silver nitrate ( $0.1 \%$ v/v) (PlusOne тм Silver Staining Kit, Protein, G.E. Healthy Care) and the Bench-Mark TM Protein Ladder marker (Invitrogen, U.S.A.) with molar mass ranging from 10 to $220 \mathrm{kDa}$, were used to rendering and identify the protein

Table 1

Selection of $\mathrm{pH}$ and temperature for determining the esterase enzymatic activity using the substrates $p$-nitrophenyl caprylate ( $p$-NPC) and $p$-nitrophenylbutyrate ( $p$-NPB).Results correspond to the average of three measurements \pm standard deviation.

\begin{tabular}{lcc}
\hline $\mathrm{pH}^{1}$ & $p$-NPC $(\mathrm{U} / \mathrm{mL})$ & $p$-NPB $(\mathrm{U} / \mathrm{mL})$ \\
\hline 5 & $1.21 \pm 0.01^{\mathrm{a}}$ & $0.80 \pm 0.01^{\mathrm{a}}$ \\
6 & $4.58 \pm 0.06^{\mathrm{b}}$ & $3.02 \pm 0.09^{\mathrm{b}}$ \\
7 & $16.31 \pm 0.26^{\mathrm{c}}$ & $20.72 \pm 0.44^{\mathrm{c}}$ \\
8 & $10.49 \pm 0.32^{\mathrm{d}}$ & $21.33 \pm 0.50^{\mathrm{d}}$ \\
9 & $17.40 \pm 0.20^{\mathrm{e}}$ & $19.47 \pm 0.19^{\mathrm{e}}$ \\
\hline Temperature $\left({ }^{\circ} \mathrm{C}\right)^{2}$ & $p$-NPC $(\mathrm{U} / \mathrm{mL})$ & $p$-NPB $(\mathrm{U} / \mathrm{mL})$ \\
\hline 30 & $16.31 \pm 0.26^{\mathrm{a}}$ & $20.72 \pm 0.44^{\mathrm{a}}$ \\
37 & $19.43 \pm 0.09^{\mathrm{b}}$ & $15.55 \pm 0.20^{\mathrm{b}}$ \\
40 & $23.80 \pm 0.27^{\mathrm{c}}$ & $17.20 \pm 0.80^{\mathrm{c}}$ \\
50 & $9.09 \pm 0.14^{\mathrm{d}}$ & $22.66 \pm 0.60^{\mathrm{d}}$ \\
60 & $5.17 \pm 0.03^{\mathrm{e}}$ & $3.66 \pm 0.09^{\mathrm{e}}$ \\
\hline
\end{tabular}

\footnotetext{
${ }^{1}$ temperature $30^{\circ} \mathrm{C}$.

${ }^{2} \mathrm{pH}$ 7.0. Different letters in the column mean the results are statistically different according to the Tukey test $(\mathrm{p}<0.05)$.
}

bands.

A zymography was carried out in native polyacrylamide gel electrophoresis cast with $4 \%$ stacking gel and $8 \%$ resolving gel to identify the active enzyme band. The gel was washed in $50 \mathrm{mM}$ Tris/ $\mathrm{HCl}(\mathrm{pH}$ 8.0) for $30 \mathrm{~min}$. Next, the gel was placed in a chromogenic agar prepared with $2 \%$ tributyrin substrate, $2 \%(\mathrm{w} / \mathrm{v})$ agar, phenol red $(0.01 \%), 10$ $\mathrm{Mm} \mathrm{CaCl}_{2}$ solution at $\mathrm{pH} 7.3$ and was further incubated at $40^{\circ} \mathrm{C}$ for $20 \mathrm{~h}$. The activity was observed as a clear yellow band corresponding to the spot at which the enzyme hydrolyzed the substrate [41].

\subsection{Effect of temperature, $p H$, and salts on the esterase stability}

The partially purified esterase's stability, obtained from the shakeflasks assays, exposed for $2 \mathrm{~h}$ to different temperatures ranging from 10 to $80{ }^{\circ} \mathrm{C}$ was evaluated [42]. Likewise, the enzyme stability at different $\mathrm{pH}$ values at $4{ }^{\circ} \mathrm{C}$ for $2 \mathrm{~h}$ was also studied. For that purpose, 50 $\mathrm{mM}$ citrate buffer ( $\mathrm{pH} 4.0-5.0$ ); $50 \mathrm{mM}$ potassium phosphate buffer (PBS) (pH 6.0-8.0) and $50 \mathrm{mM}$ Glycine-NaOH buffer (pH 9.0) were used.

The effect of different salts in the enzyme stability was tested with $5.0 \mathrm{mM}$ solution of the following ions: $\mathrm{K}^{+}, \mathrm{Mg}^{2+}, \mathrm{Na}^{+}, \mathrm{Zn}^{2+}, \mathrm{Ca}^{2+}, \mathrm{Fe}^{3+}$, $\mathrm{Ba}^{2+}, \mathrm{Al}^{3+}, \mathrm{Fe}^{2+}$, and $\mathrm{Cu}^{2+}$. The enzyme was incubated at $4{ }^{\circ} \mathrm{C}$ for $1 \mathrm{~h}$ [45]. Esterase activity was evaluated using $p$-NPC as the substrate. The enzyme reaction incubated at $4{ }^{\circ} \mathrm{C}$ was used as reference (relative activity set as $100 \%$ ).

\subsection{Kinetics parameters of partially purified esterase}

The kinetic parameters were determined with the partially purified esterase at concentrations ranging from 0.25 to $5.0 \mathrm{mM}$ using $p$-NPC and $p$-NPB as substrate. The reaction was conducted under the same conditions described in section 2.4. The $K_{m}$ and $V_{\max }$ were estimated according to the Michaelis-Menten equation using a non-linear regression algorithm.

\subsection{Biotransformation parameters}

The biotransformation parameters $\mathrm{Y}_{\mathrm{X} / \mathrm{S}}$ (cell growth yield), $\mathrm{Y}_{\mathrm{P} / \mathrm{X}}$ (product-biomass yield) and $\mathrm{Y}_{\mathrm{P} / \mathrm{S}}$ (product-substrate yield) were calculated using the following equations:

$Y_{X / S}=\frac{\left(X-X_{0}\right)}{\left(S_{0}-S\right)}$

$Y_{P / x}=\frac{\left(P-P_{0}\right)}{\left(X-X_{0}\right)}$

$Y_{P / S}=\frac{\left(P-P_{0}\right)}{\left(S_{0}-S\right)}$

The productivity (U/L.h), is defined as the ratio between esterase activity and fermentation time, was also calculated using the enzyme activity obtained with the $p$-NPC as substrate. The fermentation time used was the one at which the activity was maximal, or alternatively the end of the process if no maximal was achieved.

\subsection{Esterase application}

As different molar masses were obtained for the enzyme produced in the shake-flasks (Est-1), and in the airlift reactor (Est-2), both enzymes were evaluated as potential bioremediation agents. The enzymes were used to degrade the MACO-Sty, a new copolymer made of castor oil maleate and styrene copolymer, obtained by Maia and Fernandes [43]. The reaction mixture contained the crude esterase culture broth (10 $\mathrm{mL}$ ), and the MACO-Sty polymer $(2 \mathrm{~mL})$. The assay was carried out in a rotatory shaker ( $200 \mathrm{rpm})$ at $25{ }^{\circ} \mathrm{C}$ for 14 days.

The molecular structure of the degraded polymer was analyzed by Fourier Transform Infrared Spectroscopy (FTIR) in a Cary 630 FTIR 
Table 2

Fractional factorial design $\left(2^{3-1}\right)$ for the selection of the variables that affect the production of esterase by Aureobasidium pullulans URM 7059. Results correspond to the average of three measurements \pm standard deviation.

\begin{tabular}{|c|c|c|c|c|c|}
\hline \multirow{2}{*}{ Assays } & \multirow{2}{*}{$\begin{array}{l}\text { Glycerol } \\
(\%)\end{array}$} & \multirow{2}{*}{$\begin{array}{l}\text { Yeast extract } \\
(\mathrm{g} / \mathrm{L})\end{array}$} & \multirow{2}{*}{$\begin{array}{l}\left(\mathrm{NH}_{4}\right)_{2} \mathrm{SO}_{4} \\
(\mathrm{~g} / \mathrm{L})\end{array}$} & \multicolumn{2}{|c|}{ Esterase activity $(\mathrm{U} / \mathrm{mL})$} \\
\hline & & & & $p$-NPC & $p$-NPB \\
\hline 1 & 0.1 & 2.0 & 8.0 & $\begin{array}{l}19.79 \pm \\
0.19\end{array}$ & $\begin{array}{l}.49 .48 \pm \\
0.55\end{array}$ \\
\hline 2 & 1.9 & 2.0 & 4.0 & $\begin{array}{l}13.87 \pm \\
1.03\end{array}$ & $\begin{array}{l}9.60 \pm \\
0.62\end{array}$ \\
\hline 3 & 0.1 & 8.0 & 4.0 & $\begin{array}{l}27.61 \pm \\
2.21\end{array}$ & $\begin{array}{l}15.9 \pm \\
1.26\end{array}$ \\
\hline 4 & 1.9 & 8.0 & 8.0 & $\begin{array}{l}23.10 \pm \\
1.43\end{array}$ & $\begin{array}{l}17.4 \pm \\
1.73\end{array}$ \\
\hline $5(\mathrm{C})$ & 1.0 & 5.0 & 6.0 & $\begin{array}{l}20.41 \pm \\
0.33\end{array}$ & $\begin{array}{l}16.48 \pm \\
0.26\end{array}$ \\
\hline $6(\mathrm{C})$ & 1.0 & 5.0 & 6.0 & $\begin{array}{l}20.05 \pm \\
0.02\end{array}$ & $\begin{array}{l}16.26 \pm \\
0.48\end{array}$ \\
\hline $7(\mathrm{C})$ & 1.0 & 5.0 & 6.0 & $\begin{array}{l}19.62 \pm \\
0.41\end{array}$ & $\begin{array}{l}17.52 \pm \\
0.24\end{array}$ \\
\hline
\end{tabular}

Table 3

Central composite design $\left(2^{2}\right)$ for the optimization of esterase production by Aureobasium pullulans URM 7059. (C): central point. Results correspond to the average of three measurements \pm standard deviation.

\begin{tabular}{lllll}
\hline Assays & CSL $(\mathrm{w} / \mathrm{w}) \%$ & \multicolumn{2}{l}{ Yeast extract $(\mathrm{g} / \mathrm{L})$} & \multicolumn{2}{l}{ Esterase activity $(\mathrm{U} / \mathrm{mL})$} \\
\cline { 4 - 5 } & & & $p$-NPC & $p$-NPB \\
\hline 1 & 0.0 & 0.0 & $7.10 \pm 0.9494$ & $3.90 \pm 0.73,73$ \\
2 & 0.0 & 8.0 & $27.00 \pm 2.21$ & $15.90 \pm 1.26$ \\
3 & 8.0 & 0.0 & $7.90 \pm 1.10$ & $6.50 \pm 1.10$ \\
4 & 8.0 & 8.0 & $3.40 \pm 0.88$ & $8.80 \pm 0.30$ \\
5 & 0.0 & 4.0 & $17.00 \pm 2.30$ & $10.90 \pm 0.91$ \\
6 & 8.0 & 4.0 & $12.00 \pm 0.85$ & $4.50 \pm 0.41$ \\
7 & 4.0 & 0.0 & $21.10 \pm 0.93$ & $7.50 \pm 1.4$ \\
8 & 4.0 & 8.0 & $21.60 \pm 0.32$ & $14.60 \pm 0.86$ \\
$9(\mathrm{C})$ & 4.0 & 4.0 & $12.60 \pm 1.0$ & $7.60 \pm 0.46,73$ \\
$10(\mathrm{C})$ & 4.0 & 4.0 & $10.20 \pm 0.53$ & $8.80 \pm 0.43$ \\
$11(\mathrm{C})$ & 4.0 & 4.0 & $12.10 \pm 2.1$ & $8.60 \pm 1.44$ \\
\hline
\end{tabular}

(Agilent, USA), equipped with a diamond crystal ATR measurement accessory. FTIR spectra were collected in the region between 400 and $4000 \mathrm{~cm}^{-1}$ wavelength using a $1 \mathrm{~cm}^{-1}$ spectral resolution. All samples were applied directly into the spectrometer without any previous treatment.

\subsection{Statistical analysis}

All experiments were replicated, and all analysis were done in triplicate $(n=6)$. The statistical analysis was carried out using the Statistica software (Statsoft $\mathrm{v}$ 13.0) and proper tests for each type of result. Standardized effects were calculated for the fractional design, and F-test and ANOVA for the central composite design. Tukey tests were applied whenever comparisons of means were useful.

\section{Results and discussion}

\subsection{Selection of the optimum $\mathrm{pH}$ and temperature values for enzyme activity}

Before studying the culture medium composition, the effect of $\mathrm{pH}$ and temperature on the extracellular esterase activity was evaluated using $p$-NPC and $p$-NPB, as shown in Table 1 . The esterase produced by A. pullulans URM 7059 showed good activity at neutral $\mathrm{pH}$ for both substrates. The highest enzymatic activities for both substrates were obtained at $\mathrm{pH} 7.0$ and $\mathrm{pH}$ 9.0. The $\mathrm{pH} 7.0$ (neutral) was selected for the following enzymatic assays for both substrates. Likewise, the optimum temperature for the enzyme activity assays with each substrate was determined. For the substrate $p$-NPC, it was $40{ }^{\circ} \mathrm{C}$ with an activity of $23.80 \pm 0.27 \mathrm{U} / \mathrm{mL}$; while for $p-\mathrm{NPB}$, a maximum activity of $22.66 \pm$ $0.60 \mathrm{U} / \mathrm{mL}$ was obtained at $50{ }^{\circ} \mathrm{C}$. However, the esterase activity decreased by $40 \%$ at $50{ }^{\circ} \mathrm{C}$ when using p-NPC. Thus, the following enzyme activity assays were carried out at $40{ }^{\circ} \mathrm{C}$ and $\mathrm{pH} 7.0$ for both enzymes. Jayanath et al. [47] reported esterases with activity at mild temperatures showing a loss of $60 \%$ of activity at $55^{\circ} \mathrm{C}$ and an optimum around $40^{\circ} \mathrm{C}$. Camacho et al. [48] reported a maximum activity at $80^{\circ} \mathrm{C}$ and in the $\mathrm{pH}$ range from 6.0-7.5 for Halobacterium sp. NRC-1 esterase. The results herein obtained show that the esterase produced by A. pullulans URM 7059 is not thermotolerant. The enzyme activity sharply decreases at $60^{\circ} \mathrm{C}$ for both substrates. Regarding the optimum $\mathrm{pH}$, the esterase produced by $A$. pullulans LABIOTEC 01 was more acidic, with low activity at $\mathrm{pH}$ values higher than 7.0 [38]. The enzyme produced in the current work exhibits higher activity at $\mathrm{pH}$ values higher than 7.0. Furthermore, this esterase exhibits good activity in the $\mathrm{pH}$ range between 7.0 and 9.0, making it suitable for industrial applications since acidic $\mathrm{pH}$ imparts equipment corrosion.

\subsection{Culture medium composition for esterase production}

The results depicted in Table 2 (fractional factorial design) evidence that $A$. pullulans URM 7059 is a good esterase producer due to the high activity values obtained even in the absence of glucose. The possibility of using a residue as the carbon source can be crucial for the sustainability of the process on an industrial scale.

The effect of carbon (glycerol) and nitrogen sources (yeast extract and ammonium sulfate) on enzymatic activity were evaluated through the pareto chart presented in Figure S1 (Supplementary File). Glycerol showed a non-significant effect on the esterase activity using $p$-NPB and a negative effect using $p$-NPC substrate. Glycerol is the carbon source and must be kept in the culture medium in low concentrations to avoid the negative effect observed for $p$-NPC substrate. Yeast extract showed a positive and significant effect, while the ammonium sulfate effect was
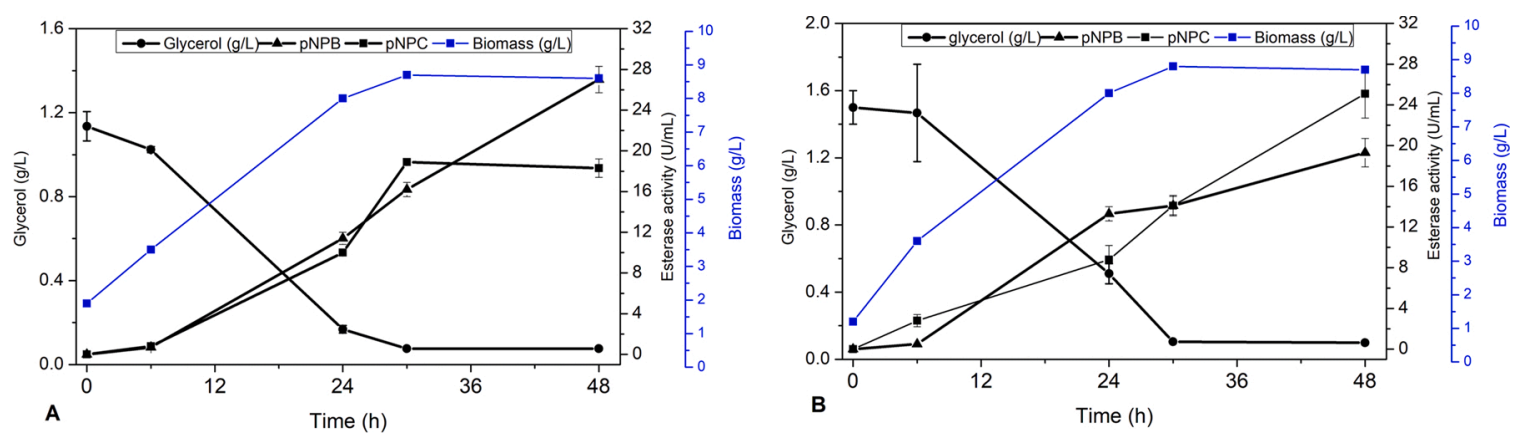

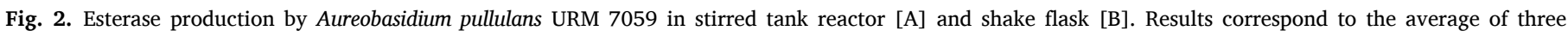
measurements \pm standard deviation. 

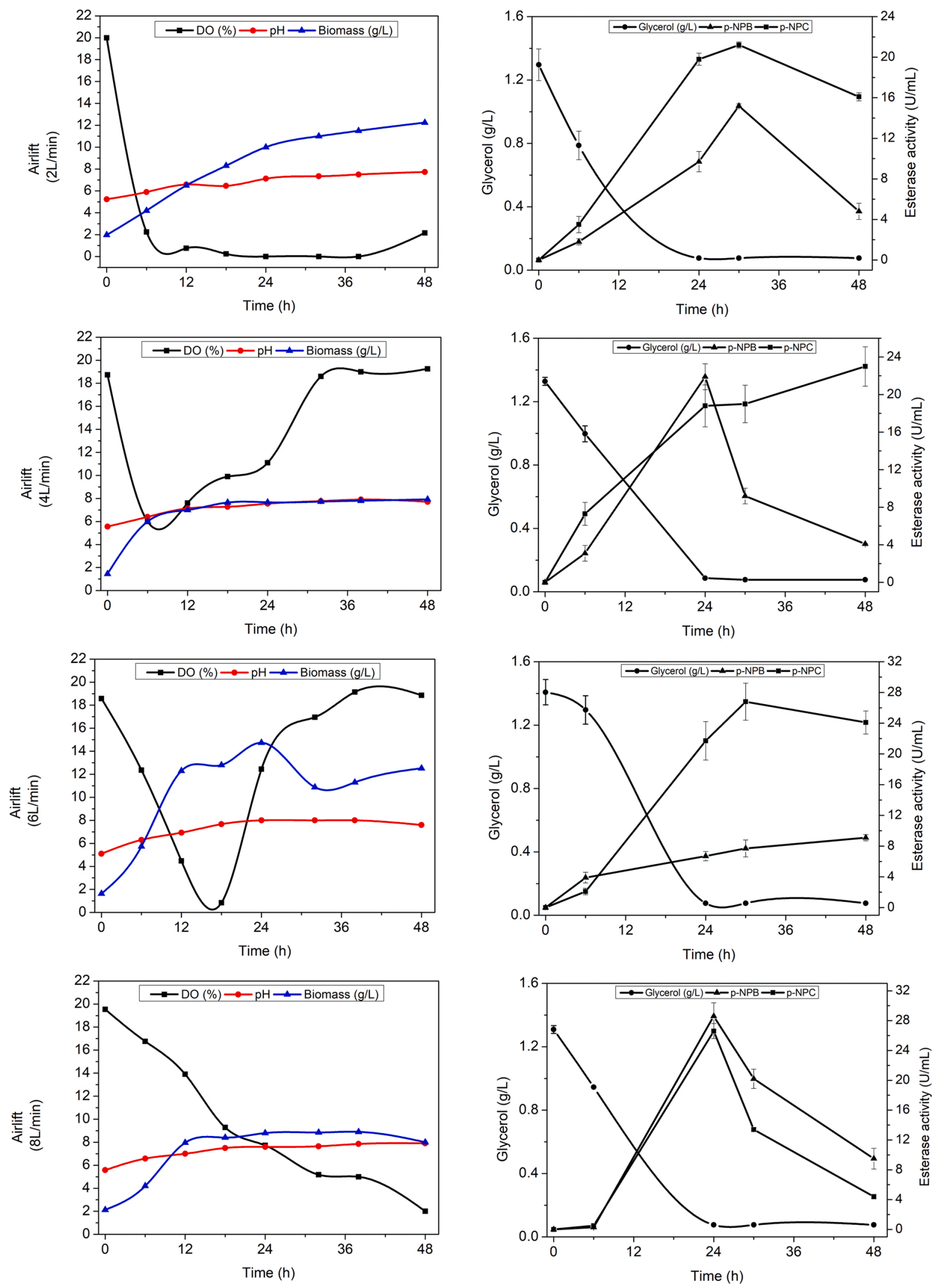

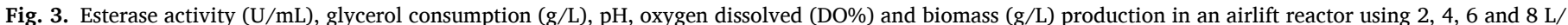
min air flow rate. Results correspond to the average of three measurements \pm standard deviation. 
Table 4

Cell growth parameters and esterase production by Aureobasidium pullulans URM 7059. Results correspond to the average of three measurements \pm standard deviation.

\begin{tabular}{|c|c|c|c|c|c|}
\hline \multirow[b]{2}{*}{ Parameters } & \multirow{2}{*}{$\begin{array}{l}\text { Stirred Tank } \\
\text { Bioreactor } \\
2 \mathrm{~L} / \mathrm{min}\end{array}$} & \multicolumn{4}{|c|}{ Airlift bioreactor } \\
\hline & & $2 \mathrm{~L} / \mathrm{min}$ & $4 \mathrm{~L} / \mathrm{min}$ & $6 \mathrm{~L} / \mathrm{min}$ & $8 \mathrm{~L} / \mathrm{min}$ \\
\hline $\mathrm{X}_{\text {máx }}(\mathrm{g} / \mathrm{L})$ & $8.85 \pm 0.5$ & $\begin{array}{l}12.3 \pm \\
0.5\end{array}$ & $7.9 \pm 0.0$ & $\begin{array}{l}14.7 \pm \\
0.3\end{array}$ & $8.0 \pm 0.2$ \\
\hline $\mathrm{t}_{\mathrm{x}, \text { máx }}(\mathrm{h})$ & 48 & 48 & 48 & 24 & 24 \\
\hline $\mathrm{S}_{\text {total }}(\mathrm{g} / \mathrm{L})$ & $1.501 \pm 0.10$ & $\begin{array}{l}1.296 \pm \\
0.10\end{array}$ & $\begin{array}{l}1.328 \pm \\
0.025\end{array}$ & $\begin{array}{l}1.408 \pm \\
0.08\end{array}$ & $\begin{array}{l}1.309 \pm \\
0.025\end{array}$ \\
\hline $\begin{array}{l}\mathrm{P}_{\mathrm{p}, \text { máx }}(\mathrm{U} / \mathrm{L} . \\
\mathrm{h})\end{array}$ & 375.0 & 825.0 & 791.6 & 904.1 & 1.108 .3 \\
\hline $\mathrm{T}_{\mathrm{p} \text {,máx }}(\mathrm{h})$ & 48 & 30 & 48 & 30 & 24 \\
\hline $\mathrm{Y}_{\mathrm{X} / \mathrm{S}}$ & $7.12 \pm 0.30$ & $\begin{array}{l}7.86 \pm \\
0.20\end{array}$ & $\begin{array}{l}5.15 \pm \\
0.50\end{array}$ & $\begin{array}{l}7.42 \pm \\
0.20\end{array}$ & $\begin{array}{l}5.43 \pm \\
0.30\end{array}$ \\
\hline $\mathrm{Y}_{\mathrm{P} / \mathrm{X}}(\mathrm{U} / \mathrm{g})$ & $2.98 \pm 0.30$ & $\begin{array}{l}2.20 \pm \\
0.57\end{array}$ & $\begin{array}{l}2.94 \pm \\
0.30\end{array}$ & $\begin{array}{l}1.92 \pm \\
0.24\end{array}$ & $\begin{array}{l}3.97 \pm \\
0.22\end{array}$ \\
\hline $\mathrm{Y}_{\mathrm{P} / \mathrm{S}}(\mathrm{U} / \mathrm{g})$ & $21.27 \pm 2.3$ & $\begin{array}{l}17.37 \pm \\
4.49\end{array}$ & $\begin{array}{l}15.17 \pm \\
1.6\end{array}$ & $\begin{array}{l}14.27 \pm \\
1.85\end{array}$ & $\begin{array}{l}21.57 \pm \\
1.22\end{array}$ \\
\hline $\mathrm{K}_{\mathrm{L}} \mathrm{a}\left(\mathrm{s}^{-1}\right)$ & $4.6 \times 10^{-4}$ & $\begin{array}{l}9.8 \times \\
10^{-4}\end{array}$ & $\begin{array}{l}1.8 \times \\
10^{-3}\end{array}$ & $\begin{array}{l}9.4 \times \\
10^{-4}\end{array}$ & $\begin{array}{l}3.5 \times \\
10^{-3}\end{array}$ \\
\hline $\mathrm{U}_{\mathrm{G}}\left(\mathrm{cm} \cdot \mathrm{s}^{-1}\right)$ & $2.22 \times 10^{-3}$ & $\begin{array}{l}2.75 \times \\
10^{-5}\end{array}$ & $\begin{array}{l}5.50 \times \\
10^{-5}\end{array}$ & $\begin{array}{l}8.26 \times \\
10^{-4}\end{array}$ & $\begin{array}{l}1.10 \times \\
10^{-4}\end{array}$ \\
\hline
\end{tabular}

non-significant $(\mathrm{p}<0.1)$. According to the results, yeast extract was essential for esterase production and cannot be removed from the culture media. Likewise, Suryia et al. [44] reported yeast extract as the best nitrogen source for cell growth. According to the results, low glycerol concentration $(0.1 \% \mathrm{v} / \mathrm{v})$ combined with the higher amounts of yeast extract $(8 \mathrm{~g} / \mathrm{L})$ increased the esterase activity. Many lipid substrates are both sources of carbon and inducers of lipolytic enzyme production [45]. Morais et al. [46] produced a lipolytic enzyme in a culture medium containing $200 \mathrm{~g} / \mathrm{L}$ of soybean molasses. The maximum lipolytic activity was $11.9 \pm 0.10 \mathrm{U} / \mathrm{mL}$ using butyrate as the substrate. Other researchers increased enzymatic activities by using genetically modified microorganisms [2], such as the esterase production by a recombinant strain of Penicillium sp. led to $0.021 \mathrm{U} / \mathrm{mL}$ activity using caprylate as substrate [47]. However, the enzyme activity obtained in the present study, determined using the same substrates, was higher than the previous studies.

After selecting the main medium components affecting esterase activity from the fractional design, a faced centered central composite experimental design (CCD) was carried out to optimize the concentration of nitrogen source (Table 3). However, the response surface methodology could not be applied because the fitted model was not statically significant given that the calculated F-value $\left(\mathrm{F}_{5.5}=2.0\right)$ was lower than the listed F-value $\left(\mathrm{F}_{5.5 / 0.05}=3.45\right)$ at $95 \%$ of confidence level. The esterase activity values ranged from $3.90 \pm 0.73-15.90 \pm 1.26 \mathrm{U} / \mathrm{mL}$ using $p$-NPB, and $3.40 \pm 0.88-27.00 \pm 2.21 \mathrm{U} / \mathrm{mL}$ using $p$-NPC as

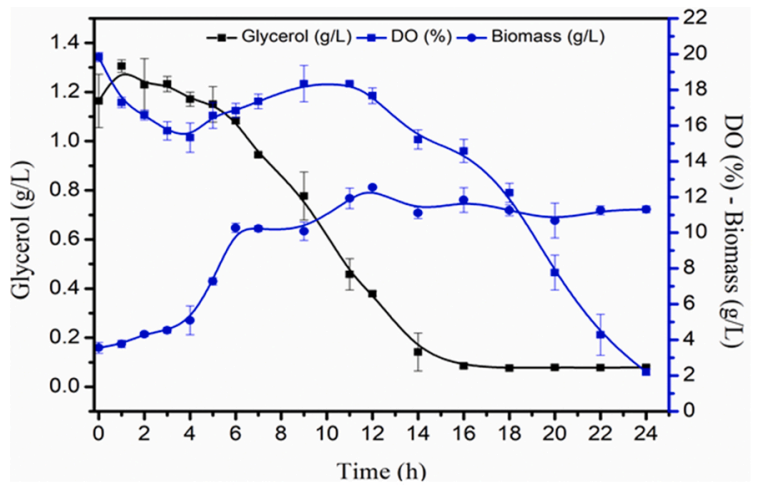

substrate. In assay 7, using $4 \mathrm{~g} / \mathrm{L}$ of CSL and no yeast extract, an esterase activity of $21.1 \pm 0.93 \mathrm{U} / \mathrm{mL}$ using $p$-NPC was obtained. For $p$-NPB, the enzyme activity was lower under the same conditions $(7.50 \pm 1.4 \mathrm{U} /$ $\mathrm{mL}$ ). On the other hand, the highest enzyme activity using both substrates was obtained in assay $2(27.00 \pm 2.21 \mathrm{U} / \mathrm{mL}$ and $15.90 \pm 1.26 \mathrm{U} /$ $\mathrm{mL}$ using $p$-NPC and $p$-NPB, respectively) using $8 \mathrm{~g} / \mathrm{L}$ of yeast extract. Regner et al. [48] concluded that a maximum esterase production by Aspergillus niger occurred in a culture medium containing $10 \mathrm{~g} / \mathrm{L}$ of peptone and cooking oil waste. In the current study, the results gathered in Tables 2 and 3 show that CSL cannot completely replace the yeast extract, which was the ideal nitrogen source for esterase production by A. pullulans URM 7059. Indeed, yeast extract and low amounts of residual glycerol are the most relevant factors. In summary, the maximum esterase activity was obtained using the culture medium composed of $0.1 \%(\mathrm{v} / \mathrm{v})$ of residual glycerol, $8 \mathrm{~g} / \mathrm{L}$ of yeast extract, $4 \mathrm{~g} / \mathrm{L}$ of $\mathrm{NH}_{4} \mathrm{SO}_{4}$, $0.4 \%(\mathrm{v} / \mathrm{v})$ of Tween 80 , and $1 \mathrm{~g} / \mathrm{L}$ of $\mathrm{KH}_{2} \mathrm{PO}_{4}$. Yeast extract is a source of amino acids, thus being essential for the esterase production.

\subsection{Esterase production in a stirred tank (STR) and airlift reactors}

Initially, the fermentation process carried out using a stirred tank reactor (STR). The results are presented in Fig. 2A. The results were compared with those obtained using a shake-flask under the same conditions (Fig. 2B) to evaluate the aeration effect on the enzyme production. Using shake-flask, the esterase activity was $25.1 \pm 2.34 \mathrm{U} / \mathrm{mL}$ ( $p$ $\mathrm{NPC})$ and $19.3 \pm 1.4 \mathrm{U} / \mathrm{mL}(p-\mathrm{NPB})$ at $48 \mathrm{~h}$. Likewise, the esterase production using shake-flask was described by [54], and activities of 1.8-11.3 U/mL ( $p$-NPB) by Candida rugosa and, $26.2 \mathrm{U} / \mathrm{mL}$ by Thermomyces lanuginosus, were reported. The esterase production by Aspergillus westerdijkiae using different vegetal oils as inducers $(1 \%, \mathrm{v} / \mathrm{v})$ resulted in a maximum esterase activity of $19-24 \mathrm{U} / \mathrm{mL}$ [49]. The results obtained in the present study using shake-flasks are within the ones reported by other authors.

The enzyme produced in STR showed a different pattern compared to the shake-flask one. Maximal activities were $18.3 \pm 0.9 \mathrm{U} / \mathrm{mL}$ ( $p$-NPC) and $27 \pm 1.3 \mathrm{U} / \mathrm{mL}$ ( $p$-NPB), which represents an increase of about $42 \%$ for the enzyme activity when measured using $p$-NPB, and a decrease of $28 \%$ in the enzyme activity when measured using $p$-NPC. Hemmerich et al. [50] studied esterase production in STR using a cloned strain of Pichia pastoris and reported a maximum esterase activity of $12 \pm 1.2$ $\mathrm{U} / \mathrm{mL}$ using glycerol as substrate and esterase activity of $9.8 \pm 0.6 \mathrm{U} / \mathrm{mL}$ when using glucose instead. The esterase productivity was higher using the STR (562 U/L.h) than the shake-flasks (395 U/L.h).

As the enzyme production in STR showed a different pattern comparing to the shake-flask, further experiments were conducted an airlift reactor (ALR), which promotes a better oxygen transfer than STR. Thus, different aeration rates were studied in the airlift reactor to evaluate its impact on esterase production (Fig. 3). Airflow rates of 4 and

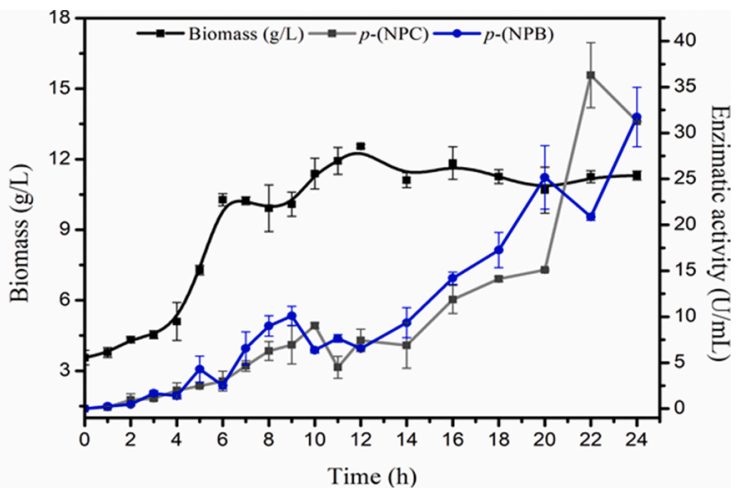

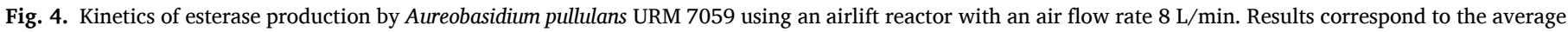
of three independent experiments \pm standard deviation. 


\section{(A)}

$\mathrm{kDa}$

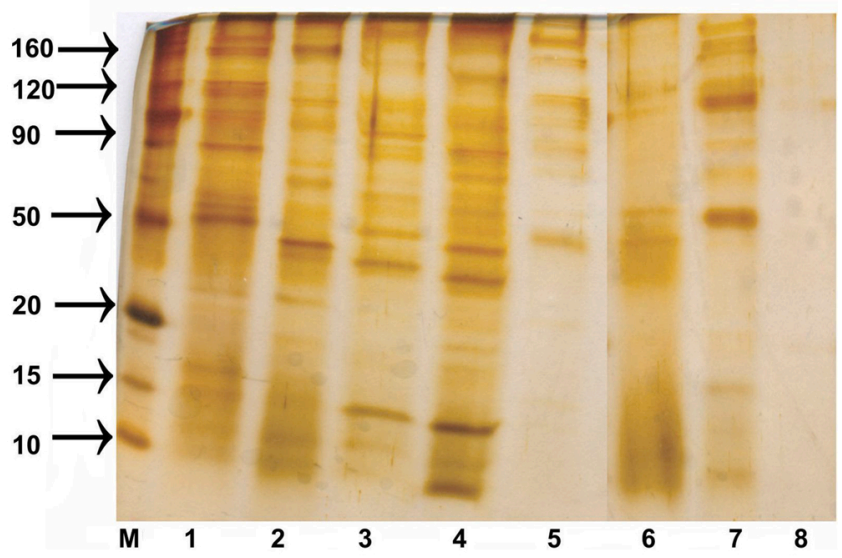

(B)

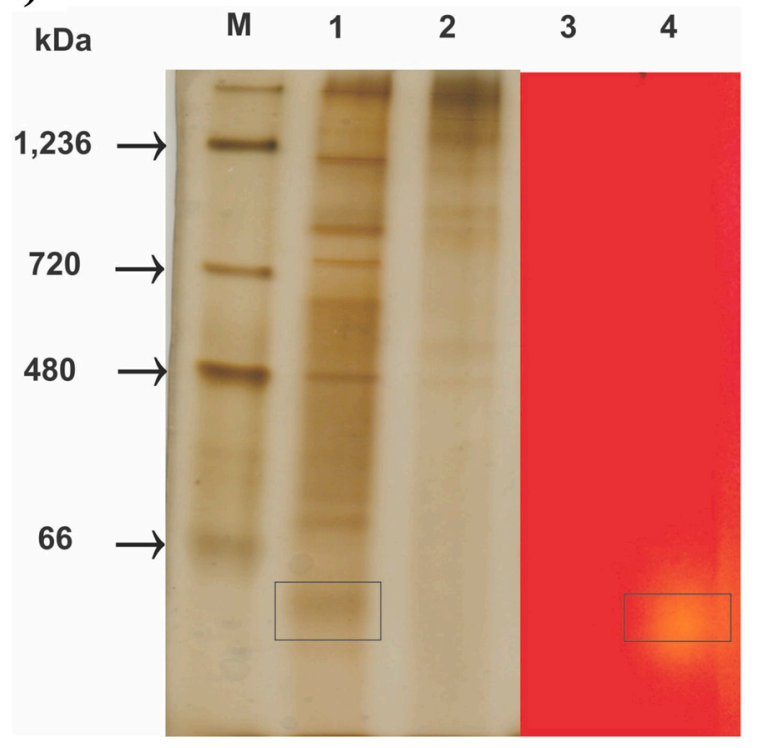

Fig. 5. Purification of the extracellular esterase produced by Aureobasidium pullulans URM 7059. (A) SDS-PAGE gel illustrating the purification steps. Lane M: protein molecular weight marker; Lane 1: cell free crude broth; Lane 2: PEG 1500; Lane 3: PEG 4000 and Lane 4: PEG 6000; Lane 5: dialyzed crude broth supernatant; Lane 6: $30 \%(\mathrm{w} / \mathrm{v})\left(\mathrm{NH}_{4}\right)_{2} \mathrm{SO}_{4}$ fraction; Lane 7: 30-90 \% (w/v) $\left(\mathrm{NH}_{4}\right)_{2} \mathrm{SO}_{4}$ fraction; Lane 8: culture medium. (B) Native PAGE of the process steps by precipitation with $\left(\mathrm{NH}_{4}\right)_{2} \mathrm{SO}_{4}$ (Lane 1) and PEG 6000 (Lane 2). Zymogram (Lane 3 and 4) identifying the activity of the protein bands.

$8 \mathrm{~L} / \mathrm{min}$ favored esterase production. At low aeration $(2 \mathrm{~L} / \mathrm{min})$, the complete oxygen depletion occurred at $12 \mathrm{~h}$, and despite the airflow was kept at the same rate until the processing end, the oxygen provided was readily consumed by the yeast. At a higher airflow rate, the stationary phase was obtained after $12 \mathrm{~h}$, and the oxygen levels increased for the assays performed at 4 and $6 \mathrm{~L} / \mathrm{min}$. The highest biomass was obtained with aeration at $6 \mathrm{~L} / \mathrm{min}$. However, the enzyme productivity was higher when applying aeration of $8 \mathrm{~L} / \mathrm{min}$ (a shorter time to attain the peak of maximal enzyme production). A proper comparison among the different bioprocesses under study was done using the transformation parameters given in Eqs. 1-3 (Table 4). Glycerol was depleted at $24 \mathrm{~h}$, followed by the enzyme activity increase. The differences in biomass show that the aeration rate affects microbial growth. The maximum enzyme activity was found in the stationary growth phase. Aside from the airflow rate, this type of reactor can also influence the enzyme activity due to the aeration system, stirring, and mixing [51]. Altogether these factors contributed to better productivity when using the airlift reactor, with 1191 U/L.h ( $p$-NPB) and 1108 U/L.h (p-NPC). The maximum esterase activity was obtained with an airflow of $8 \mathrm{~L} / \mathrm{min}$, namely $26.6 \pm 1.5$ $\mathrm{U} / \mathrm{mL}$ and $28.6 \pm 1.8 \mathrm{U} / \mathrm{mL}$ for $p$-NPC and $p$-NPB, respectively. Burkert et al. [52] reported that increasing airflow rates led to maximum lipase production using an airlift reactor. The fermentation parameters obtained for the STR and airlift reactor are presented in Table 4. The airflow rate increase positively affected the cell growth $\left(X_{\max }\right.$ and $\left.t_{x, \max }\right)$ and esterase production $\left(\mathrm{P}_{\mathrm{p}, \max }\right)$. The highest productivity (1108.3 U/L. $\mathrm{h}$ ) and the lowest processing time ( $24 \mathrm{~h}$ obtained in the airlift reactor with an $8 \mathrm{~L} / \mathrm{min}$ air flow rate) shows that ALR is the right choice for esterase production by $A$. pullulans URM 7059. Indeed, the esterase productivity was 3-fold higher in half of the time using the airlift reactor than the STR. This better performance is due to a better mass transfer and cell dispersion obtained in the airlift reactor. The $\mathrm{Y}_{\mathrm{P} / \mathrm{S}}$ was similar in STR $(21.27 \pm 2.3 \mathrm{U} / \mathrm{g})$ and airlift reactor $(21.57 \pm 1.22 \mathrm{U} / \mathrm{g})$ at an airflow rate of $8 \mathrm{~L} / \mathrm{min}$. Despite similar biomass obtained in both reactors $(\sim 8 \mathrm{~g} / \mathrm{L})$, the cell growth was faster in the airlift reactor. The $\mathrm{Yx} / \mathrm{s}$ was significantly lower, indicating more efficient cell cultivation targeting the enzyme production.

The airlift reactor increased esterase productivity, suggesting that the maximum activities are related to the higher airflow rate. Under an airflow rate of $8 \mathrm{~L} / \mathrm{min}$, the esterase activity was $31 \mathrm{U} / \mathrm{mL}$, and the glycerol concentration was $0.079 \mathrm{~g} / \mathrm{L}$ at $24 \mathrm{~h}$ of fermentation (Fig. 4). The fast consumption of glycerol was associated with exponential biomass growth, which led to a decrease in dissolved oxygen. Jesus et al. [51] concluded that airlift reactors' use is advantageous for processes using culture media with high viscosity medium because ALR promotes better oxygen transfer rates. The culture medium used in the current study was not viscous given to the low amounts of glycerol $0.1 \mathrm{v} / \mathrm{v}$ ) used. On the other hand, ALR represents an attractive reactor because it is easier and cheaper whenever scaling up is envisaged and holds lower maintenance costs than the STR.

Overall, the process scalability when comparing shake-flask and bioreactors was demonstrated for esterase production by A. pullulans URM 7059. These results are also in good agreement with studies that reported that ALR comprises the best options for bioprocesses using fungi and yeasts due to their lower shear rates that preserve cells' integrity [53]. The esterase production by A. pullulans URM 7059 was improved using an airlift bioreactor configuration, and with increasing air flows, the process holds great promise for further industrial scale-up.

\subsection{Enzyme partial purification and characterization}

\subsubsection{Esterase precipitation}

The protein profile of the crude enzyme extract from the shake-flask fermentation is presented in Fig. 5A. The SDS PAGE gel shows the partially purified fractions precipitated according to the different protocols described in Table 5, namely using PEGs (Lane 2, 3, and 4) and ammonium sulfate (Lane 6, 7, and 8). According to the enzyme-specific activity $(\mathrm{U} / \mathrm{mg}$ ) of each fraction, it is possible to infer the esterase's successful precipitation using PEG 6000 or $\mathrm{NH}_{4} \mathrm{SO}_{4} 30 / 90$, followed by PEG 4000.

Native electrophoresis and zymography allowed the identification of the active protein bands. The lanes with esterase activity were Lane 7 (ammonium sulfate) and Lane 4 (PEG 6000. Fig. 5B shows that the protein band with esterase activity corresponds to an average molecular mass of about $50 \mathrm{kDa}$. This result is similar to the one reported for the esterase produced by Aureobasidium melanogenum HN6.2, which presented a molar mass of $60.2 \mathrm{kDa}$ [54]. The molar mass of the partially purified esterase from Achromobacter denitrifican was $53 \mathrm{kDa}$ [55], and the one from Bacillus megaterium was $55 \mathrm{kDa}$ [13]. Hence, the esterase's molar mass from A. pullulans URM 7950 is in good agreement with the literature's general notion. 
Table 5

Purification of the extracellular esterase produced by Aureobasidium pullulans URM 7059.

\begin{tabular}{|c|c|c|c|c|c|c|c|c|c|}
\hline \multirow[t]{2}{*}{ Purification steps } & \multirow{2}{*}{$\begin{array}{l}\text { Total protein } \\
(\mathrm{mg})\end{array}$} & \multicolumn{2}{|l|}{ Total activity (U) } & \multicolumn{2}{|c|}{ Specific activity (U/mg) } & \multicolumn{2}{|l|}{ Yield (\%) } & \multicolumn{2}{|c|}{ Purification (fold) } \\
\hline & & $p$-NPB & $p$-NPC & $p$-NPB & $p$-NPC & $p$-NPB & $p$-NPC & $p$-NPB & $p$-NPC \\
\hline Culture supernatant & $714.66 \pm 6.14$ & $\begin{array}{l}3640.00 \pm \\
183.0^{\mathrm{a}}\end{array}$ & $\begin{array}{l}2225.00 \pm \\
188.74^{\mathrm{a}}\end{array}$ & $\begin{array}{l}5.00 \pm \\
0.20^{\mathrm{a}}\end{array}$ & $\begin{array}{l}3.11 \pm \\
0.30^{\mathrm{a}}\end{array}$ & $100.00^{\mathrm{a}}$ & $100.00 \mathrm{a}$ & $1.00^{\mathrm{a}}$ & $1.00^{\mathrm{a}}$ \\
\hline PEG 1500 & $29.84 \pm 0.27$ & $138.66 \pm 10.3^{b}$ & $111.33 \pm 8.0^{\mathrm{b}}$ & $\begin{array}{l}4.64 \pm \\
0.30^{\mathrm{a}}\end{array}$ & $\begin{array}{l}3.73 \pm \\
0.30^{\mathrm{a}}\end{array}$ & $3.80 \pm 0.20^{\mathrm{b}}$ & $5.04 \pm 0.76^{\mathrm{b}}$ & $\begin{array}{l}0.91 \pm \\
0.00^{\mathrm{b}}\end{array}$ & $\begin{array}{l}1.20 \pm \\
0.20^{\mathrm{b}}\end{array}$ \\
\hline PEG 4000 & $26.65 \pm 0.86$ & $159.33 \pm 10.0^{c}$ & $90.66 \pm 9.45^{c}$ & $\begin{array}{l}5.98 \pm \\
0.40^{\mathrm{b}}\end{array}$ & $\begin{array}{l}3.39 \pm \\
0.20^{\mathrm{a}}\end{array}$ & $4.37 \pm 0.00^{c}$ & $4.11 \pm 0.7^{\mathrm{b}}$ & $\begin{array}{l}1.17 \pm \\
0.00^{\mathrm{c}}\end{array}$ & $\begin{array}{l}1.10 \pm \\
0.20^{\mathrm{b}}\end{array}$ \\
\hline PEG 6000 & $18.37 \pm 0.51$ & $\begin{array}{l}154.66 \pm \\
20.3^{\mathrm{b}, \mathrm{c}}\end{array}$ & $114.40 \pm 8.11^{\mathrm{b}}$ & $\begin{array}{l}8.41 \pm \\
0.90^{c}\end{array}$ & $\begin{array}{l}6.23 \pm \\
0.60^{\mathrm{b}}\end{array}$ & $4.24 \pm 0.20^{c}$ & $5.17 \pm 0.7^{\mathrm{b}}$ & $\begin{array}{l}1.65 \pm \\
0.10^{\mathrm{d}}\end{array}$ & $\begin{array}{l}2.00 \pm \\
0.30^{\mathrm{c}}\end{array}$ \\
\hline Dialysis & $642.73 \pm 7.85$ & $\begin{array}{l}1616.80 \pm \\
36.5^{\mathrm{d}}\end{array}$ & $\begin{array}{l}2476.80 \pm \\
54.73^{\mathrm{d}}\end{array}$ & $\begin{array}{l}2.51 \pm \\
0.30^{\mathrm{d}}\end{array}$ & $\begin{array}{l}4.07 \pm \\
0.40^{\mathrm{a}}\end{array}$ & $\begin{array}{l}44.34 \pm \\
3.80^{\mathrm{d}}\end{array}$ & $\begin{array}{l}117.71 \pm \\
5.12^{\mathrm{c}}\end{array}$ & $\begin{array}{l}0.49 \pm \\
0.00^{\mathrm{e}}\end{array}$ & $\begin{array}{l}1.30 \pm \\
0.00^{\mathrm{b}}\end{array}$ \\
\hline Culture supernatant & $648.00 \pm 17.21$ & $\begin{array}{l}2770.00 \pm \\
258.6^{\mathrm{A}}\end{array}$ & $\begin{array}{l}2080.00 \pm \\
34.64^{\mathrm{A}}\end{array}$ & $\begin{array}{l}4.28 \pm \\
0.50^{\mathrm{A}}\end{array}$ & $\begin{array}{l}3.21 \pm \\
0.00^{\mathrm{A}}\end{array}$ & $100.00^{\mathrm{A}}$ & $100.00^{\mathrm{A}}$ & $1.00^{\mathrm{A}}$ & $1.00^{\mathrm{A}}$ \\
\hline $30 \%\left(\mathrm{NH}_{4}\right)_{2} \mathrm{SO}_{4}$ fraction & $14.23 \pm 1.0$ & $13.65 \pm 3.0^{\mathrm{B}}$ & $10.75 \pm 3.86^{\mathrm{B}}$ & $\begin{array}{l}0.95 \pm \\
0.20^{\mathrm{B}}\end{array}$ & $\begin{array}{l}0.74 \pm \\
0.20^{\mathrm{B}}\end{array}$ & $\begin{array}{l}0.38 \pm \\
0.00^{\mathrm{B}}\end{array}$ & $0.48 \pm 0.15^{\mathrm{B}}$ & $\begin{array}{l}0.22 \pm \\
0.00^{\mathrm{B}}\end{array}$ & $\begin{array}{l}0.24 \pm \\
0.00^{\mathrm{B}}\end{array}$ \\
\hline $\begin{array}{l}30-90 \% \\
\left(\mathrm{NH}_{4}\right)_{2} \mathrm{SO}_{4} \text { fraction }\end{array}$ & $132.39 \pm 10.95$ & $506.00 \pm 3.5^{\mathrm{C}}$ & $\begin{array}{l}1348.00 \pm \\
68.63^{\mathrm{C}}\end{array}$ & $\begin{array}{l}3.84 \pm \\
0.30^{\mathrm{A}}\end{array}$ & $\begin{array}{l}10.24 \pm \\
1.20^{\mathrm{C}}\end{array}$ & $\begin{array}{l}13.90 \pm \\
0.60^{\mathrm{C}}\end{array}$ & $\begin{array}{l}61.04 \pm \\
8.16^{\mathrm{C}}\end{array}$ & $\begin{array}{l}0.89 \pm \\
0.00^{\mathrm{C}}\end{array}$ & $\begin{array}{l}3.33 \pm \\
0.70^{\mathrm{C}}\end{array}$ \\
\hline
\end{tabular}

Different letters means that statistical significance according to the Tukey test $(\mathrm{p}<0.05)$.

Table 6

Effect of different metal ions on the esterase activity produced byAureobasidium pullulans URM 7059. Results correspond to the average of three measurements \pm standard deviation.

\begin{tabular}{lll}
\hline Metal ion & Concentration $(\mathrm{mM})$ & Relative enzyme activity (\%) \\
\hline Control & 0.0 & 100.00 \\
$\mathrm{~K}^{+}$ & 5.0 & $14.71 \pm 1.95^{\mathrm{a}}$ \\
$\mathrm{Mg}^{2+}$ & 5.0 & $15.43 \pm 1.54^{\mathrm{a}}$ \\
$\mathrm{Na}^{+}$ & 5.0 & $19.45 \pm 1.90^{\mathrm{b}}$ \\
$\mathrm{Zn}^{2+}$ & 5.0 & $22.22 \pm 1.19^{\mathrm{c}}$ \\
$\mathrm{Ca}^{2+}$ & 5.0 & $46.90 \pm 5.48^{\mathrm{d}}$ \\
$\mathrm{Fe}^{3+}$ & 5.0 & $77.66 \pm 8.80^{\mathrm{e}}$ \\
$\mathrm{Ba}^{2+}$ & 5.0 & $67.60 \pm 1.12^{\mathrm{f}}$ \\
$\mathrm{Al}^{3+}$ & 5.0 & $82.18 \pm 6.22^{\mathrm{e}} \mathrm{h}$ \\
$\mathrm{Fe}^{2+}$ & 5.0 & $62.43 \pm 3.17^{\mathrm{b}}$ \\
$\mathrm{Cu}^{2+}$ & 5.0 & $91.84 \pm 6.72^{\mathrm{h}}$ \\
\hline
\end{tabular}

Different letters means that statistical significance according to the Tukey test ( $\mathrm{p}$ $<0.05)$.

3.4.2. Effect of temperature, $p H$, and metal ions on the esterase stability

The partially purified esterase presented a maximum activity at $\mathrm{pH}$ 7.0 with good stability in the range from 5.0 to 7.0 as presented in Figure S2 (Supplementary Material). This result is aligned with other studies reporting the esterase stability at $\mathrm{pH}$ values ranging from 6.0 to 8.0 [63,64]. Additionally, the enzyme was unstable at temperatures higher than $30{ }^{\circ} \mathrm{C}$. The maximum enzyme relative activity was at the lowest temperature evaluated $\left(10^{\circ} \mathrm{C}\right)$. These results are similar to those reported for the esterase from Fusarium sp., which was stable at $\mathrm{pH} 6.0$ and temperatures below $40{ }^{\circ} \mathrm{C}$ [56]. Also, alkaline esterase from Lysinibacillus fusiformis was stable at $30^{\circ} \mathrm{C}$ [57]. According to the previous studies, esterases are stable at temperatures ranging from 30 to $40{ }^{\circ} \mathrm{C}$, with a decrease in residual activity at $50{ }^{\circ} \mathrm{C}$ [66]. The esterase herein produced retained $85 \%$ of its activity at $30{ }^{\circ} \mathrm{C}$. Psychrophilic enzymes exhibit high efficiency at the activation energy due to their flexibility during substrate binding, thus favoring low energy consumption reaction [58]. Thus, esterases active at low temperatures are very interesting for the food and beverage industries [59].

The effect of metal ions markedly decreased the enzyme relative activity (Table 6). $\mathrm{K}^{+}, \mathrm{Mg}^{2+}, \mathrm{Na}^{+}$, and $\mathrm{Zn}^{2+}$ promoted an $80 \%$ inhibition of enzyme activity. On the other hand, the metal ions $\mathrm{Cu}^{2+}$ and $\mathrm{Al}^{3+}$ led to esterase activity values of approximately $90 \%$. Thus, $\mathrm{Cu}^{+2}$ and $\mathrm{Al}^{+3}$ present a slight effect on esterase activity. The esterase's residual activity produced by the yeast Glaciozyma antarctica was null in the presence of $\mathrm{Zn}^{2+}$ [20]. In contrast, the esterase from A. pullulans URM 7059 maintained $22 \%$ of the initial activity when $\mathrm{Zn}^{2+}$ was added to the

\section{$\mathrm{kDa}$}

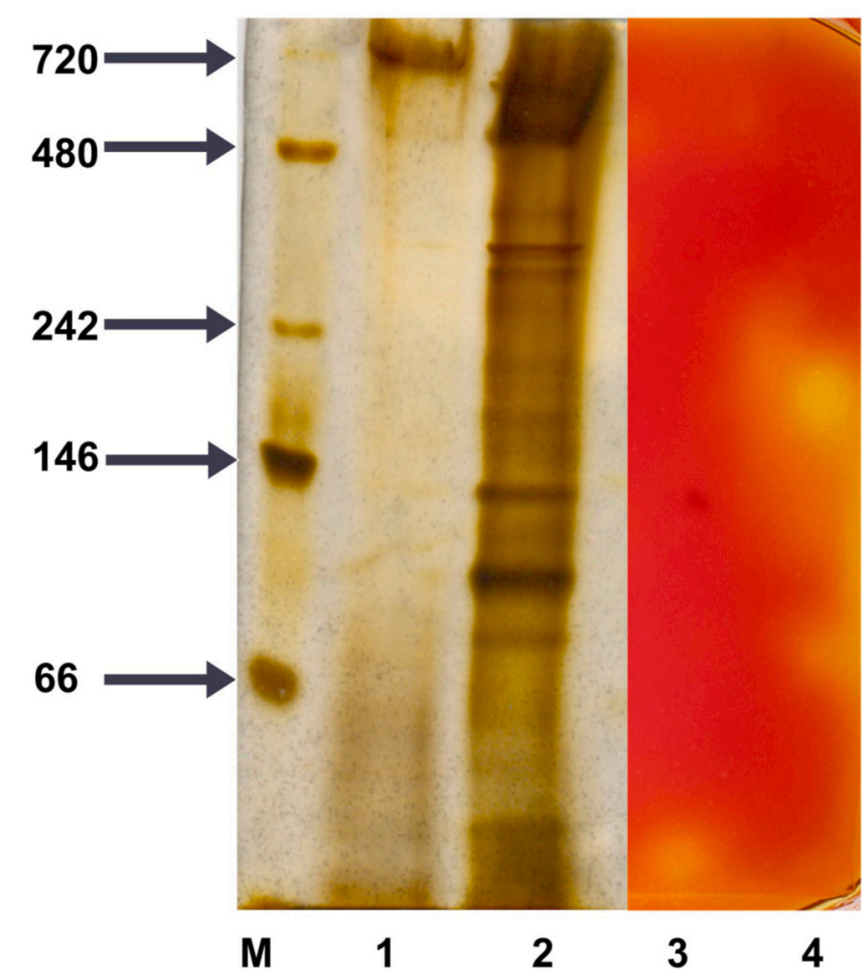

Fig. 6. Native-PAGE gel and zymogram: Lane 1,2 (protein precipitation by $\left(\mathrm{NH}_{4}\right)_{2} \mathrm{SO}_{4}$ ); Lane 3, 4 (performed to identify the activity of the protein bands); $\mathrm{M}$ (protein molecular weight marker).

buffer. Contrarily to $\mathrm{Cu}^{+2}$ and $\mathrm{Al}^{+3}, \mathrm{Zn}^{+2}$ seems to be strongly deleterious for esterase. The esterase produced by A. pullulans LABIOTEC01 showed a slight activity increase in the presence of $\mathrm{Cu}^{+2}, \mathrm{Fe}^{+3}$ and $\mathrm{Mn}^{+2}$ [38].

\subsubsection{Kinetic parameters}

The Michaelis-Menten kinetics parameters were $1.4 \mathrm{mM}\left(\mathrm{K}_{\mathrm{m}}\right)$ and $218 \mu \mathrm{mol} \mathrm{min}^{-1}\left(\mathrm{~V}_{\max }\right)$ and $1.55 \mathrm{mM}\left(\mathrm{K}_{\mathrm{m}}\right)$ and $76.76 \mu \mathrm{mol} \mathrm{min}^{-1}\left(\mathrm{~V}_{\max }\right)$ using $p$-NPC and $p$-NPB, respectively as presented in Figure S3 (Supplementary Material). This esterase presents a higher affinity to 


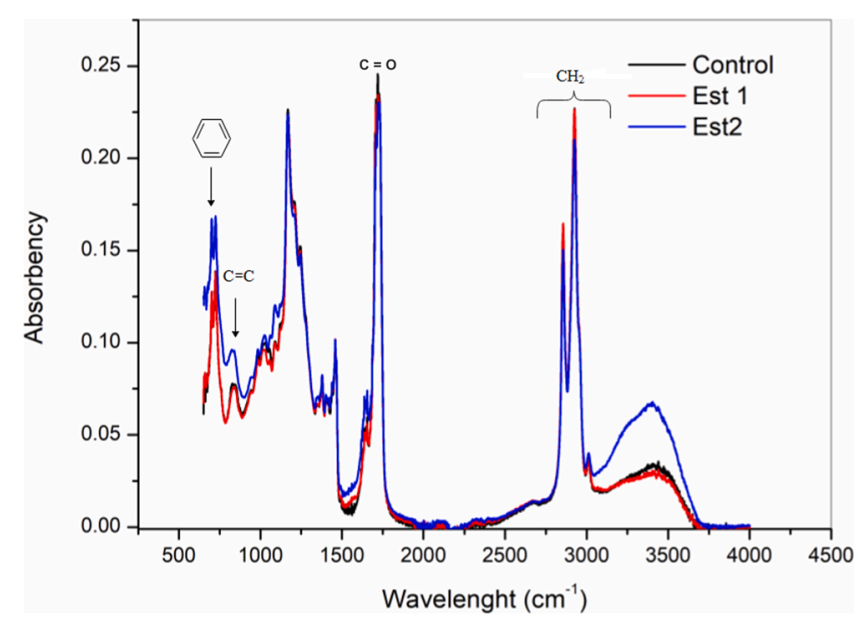

Fig. 7. Fourier Transformed Infrared Spectroscopy (FTIR) spectrum of the polymer MACO-Sty exposed to the esterases Est1 (produced on shake-flasks) and Est2 (produced in airlift). Control stands for the MACO-Sty non-exposed to esterases.

caprylate compared to butyrate. The enzyme catalytic efficiency depends not only on its source, but also on its substrate [60]. Ozcan et al. [61] reported $\mathrm{K}_{\mathrm{m}}$ values in the range $0.437-1.363 \mathrm{mM}$ using $p$-NPB as a substrate for esterase produced by different strains. Esterase produced by Pichia pastoris kinetic parameters were $1.34 \mathrm{mM}\left(\mathrm{K}_{\mathrm{m}}\right)$ and $22 \mu \mathrm{mol}$ $\min ^{-1}\left(\mathrm{~V}_{\max }\right)$ using p-NPB as substrate [62], showing a higher affinity with butyrate compared to A. pullulans URM 7059.

\subsection{Characterization of the crude esterase produced in the airlift reactor}

Esterase was found to be stable at $\mathrm{pH}$ values ranging from 7.0 to 9.0. At $\mathrm{pH}$ values below 6.0, the enzyme relative activity was below $40 \%$ (Figure S4). Regarding the esterase stability to temperature (Figure S4), the relative enzyme activity was $98 \%$ at $40{ }^{\circ} \mathrm{C}$ and bout $85-90 \%$ at temperatures ranging from $50{ }^{\circ} \mathrm{C}$ to $80^{\circ} \mathrm{C}$. The lowest relative activity was found at $30^{\circ} \mathrm{C}$, and the enzyme showed good stability at 10 and 20 ${ }^{\circ} \mathrm{C}$.

Although the same strain and culture medium were used in the shake-flask and airlift reactor, the enzymes' stability at different temperatures and $\mathrm{pH}$ was different, suggesting that different crude enzymes were produced in the different fermentation setups. Fig. 6 presents the esterase's zymogram (native-PAGE gel) produced by A. pullulans URM 7059 in the airlift reactor (at the best airflow rate, $8 \mathrm{~L} / \mathrm{min}$ ). The precipitation protocols using $\mathrm{NH}_{4} \mathrm{SO}_{4}$ are presented in Table S2 (Supplementary Material). The molar mass of this esterase was approximately $172 \mathrm{kDa}$. However, the zymogram shows two additional active bands in the native gel with approximately $66 \mathrm{kDa}$ and $40 \mathrm{kDa}$. This zymogram confirms that the enzyme previously produced in shake-flask with 50 $\mathrm{kDa}$ is different from this crude mixture produced in airlift (with 3 active bands). These results corroborate with differences observed in the enzyme's stability at different temperatures and pHs. The higher aeration rate, the different shear stress, and mass transfer phenomena in the airlift reactor justifies the differences observed in the produced enzymes'. The different operational conditions affect the genes involved in the yeast protein biosynthesis and expression [61]. Alex et al. [63] reported an esterase with a molar mass of $175 \mathrm{kDa}$ produced by Pseudozyma sp. Oleas et al. [18] analyzed three esterases produced by Penicillium purpurogenum and reported molar masses of $58 \mathrm{kDa}, 38$ $\mathrm{kDa}$, and $32 \mathrm{kDa}$. Although more than one enzyme active band was produced in the airlift reactor, as indicated in the zymogram, the molar masses obtained are within the range reported by other authors for microbial esterases.

\subsection{An application of the esterases}

The FTIR spectrum of the polymer MACO-St after exposure to the esterases previously produced (Est-1 (produced in shake-flask) and Est-2 (produced in airlift)) was compared to the control (polymer nonexposed to esterases) (Fig. 7). The peaks that correspond to the ester bonds $(\mathrm{C}=\mathrm{O})$ at $1720 \mathrm{~cm}^{-1}$ show the polymer's partial degradation by Est-1 and Est-2. Regarding Est-2, the attenuation of the peaks $2840 \mathrm{~cm}^{-1}$ and $2960 \mathrm{~cm}^{-1}$ followed by the increase of the peaks $698 \mathrm{~cm}^{-1}$ and 757 $\mathrm{cm}^{-1}$ corresponding to $\mathrm{CH}_{2}$ group (benzene ring in the polymer) indicates the conformational polymer changes. The increment in the signals at $950.14 \mathrm{~cm}^{-1}$ is also due to increased $\mathrm{CC}=$ groups, indicating the polymer degradation at the bond between MACO and styrene monomers, were observed. Thereby, Est-2 exhibited biodegradative activity, degrade the polymer in just 14 days, and enable recycling of its monomer precursors [64].

MACO-St is a polymer resin that is used to produce films. The biodegradation of films in the soil environment, without enzymatic action, can vary from 1 to 12 months, depending on the type of material and local conditions [65]. Studies on pollutant degradation have been increasingly reported in the last 4 years, although only few studies report the esterase's' role in waste hydrolysis [66]. Therefore, these results suggest that the esterases herein produced are interesting and worth further research, namely in what regards it is possible ability to degrade other polymeric compounds.

\section{Conclusion}

The results gathered in this work show that the best esterase production by $A$. pullulans URM 7059 was obtained using a culture medium containing glycerol $(0.1 \% \mathrm{v} / \mathrm{v}),\left(\mathrm{NH}_{4}\right)_{2} \mathrm{SO}_{4}(4 \mathrm{~g} / \mathrm{L})$, yeast extract $(8 \mathrm{~g} /$ $\mathrm{L})$, Tween $80(0.4 \% \mathrm{v} / \mathrm{v})$ and $\mathrm{KH}_{2} \mathrm{PO}_{4}(1 \mathrm{~g} / \mathrm{L})$. The partially purified esterase exhibits an estimated molecular mass of $50 \mathrm{kDa}$. Moreover, the enzyme activity was not beneficially affected by the presence of metals, thus indicating that the enzyme does not need a metallic co-factor. The esterase produced in shake-flasks is stable at neutral $\mathrm{pH}$ and temperatures below $30^{\circ} \mathrm{C}$. In the second step, it was observed that the airlift reactor improved the production of esterases by A. pullulans URM 7059, at the airflow rate of $8 \mathrm{~L} / \mathrm{min}$, possibly due to a better mass transfer. Thus, this bioreactor configuration holds great promise for the industrial scale-up. Moreover, the esterase was partially characterized and showed 3 active bands ( $172 \mathrm{kDa}, 66 \mathrm{kDa}$, and $40 \mathrm{kDa}$ ). The esterase produced in the airlift reactor was able to degrade the MACO-St polymer, being potentially an eco-friendly alternative for pollutant degradation. The novel esterase produced using the airlift reactor was stable at a wide range of temperatures $\left(40{ }^{\circ} \mathrm{C}-80{ }^{\circ} \mathrm{C}\right)$ and $\mathrm{pH}$ values $(7.0-9.0)$. The conditions used in the airlift strongly affected the microbial metabolism, and different enzymes were produced as compared to the shake-flask fermentation.

\section{CRediT authorship contribution statement}

Dayana P. Meneses: Methodology, Investigation, Data curation, Writing - original draft. Livia Maria N. Paixão: Methodology, Investigation, Data curation. Thatyane V. Fonteles: Methodology, Investigation, Software. Eduardo J. Gudiña: Methodology, Investigation, Validation. Ligia R. Rodrigues: Conceptualization, Methodology, Investigation, Validation, Funding acquisition, Writing - review \& editing, Funding acquisition. Fabiano A.N. Fernandes: Conceptualization, Methodology, Investigation, Validation. Sueli Rodrigues: Conceptualization, Investigation, Methodology, Supervision, Funding acquisition, Project administration, Writing - review \& editing, Funding acquisition. 


\section{Declaration of Competing Interest}

The authors report no declarations of interest.

\section{Acknowledgements}

This study was supported by the Portuguese Foundation for Science and Technology (FCT) under the scope of the strategic funding of UID/ BIO/04469/2020 unit and BioTecNorte operation (NORTE-01-0145FEDER-000004), projects MultiBiorefinery (POCI-01-0145-FEDER016403) and Lignozymes (POCI-01-0145-FEDER-029773), all funded by the European Regional Development Fund under the scope of Norte2020 - Programa Operacional Regional do Norte. In Brazil, this study was financed in part by the Coordenação de Aperfeiçoamento de Pessoal de Nível Superior - Brasil (CAPES) - Finance Code 001. The authors also thank the CNPq and FUNCAP for financial support.

\section{Appendix A. Supplementary data}

Supplementary material related to this article can be found, in the online version, at doi:https://doi.org/10.1016/j.bej.2021.107954.

\section{References}

[1] M. Schmidt, D. Böttcher, U.T. Bornscheuer, Protein engineering of carboxyl esterases by rational design and directed evolution, Protein Pept. Lett. 16 (2009) 1162-1171, https://doi.org/10.2174/092986609789071216.

[2] S.V. Valenzuela, A. Fillat, F.I.J. Pastor, P. Diaz, Biochimie Unusual carboxylesterase bearing a GGG (A) X-type oxyanion hole discovered in Paenibacillus barcinonensis BP-23 n Infanz o, Biochimie 104 (2014) 108-116, https://doi.org/10.1016/j. biochi.2014.06.003.

[3] T. Zhang, H. Chen, Z. Ni, R. Tian, J. Jia, Z. Chen, S. Yang, Expression and Characterization of a New Thermostable Esterase from Clostridium thermocellum, Appl. Biochem. Biotechnol. 177 (2015) 1437-1446, https://doi.org/10.1007/ s12010-015-1824-7.

[4] M.E. Vaquero, J. Barriuso, M.J. Martínez, A. Prieto, Properties, structure, and applications of microbial sterol esterases, Appl. Microbiol. Biotechnol. (2016), https://doi.org/10.1007/s00253-015-7258-x.

[5] Y. Hotta, S. Ezaki, H. Atomi, T. Imanaka, Extremely stable and versatile carboxylesterase from a hyperthermophilic archaeon, Appl. Environ. Microbiol. 68 (2002) 3925-3931, https://doi.org/10.1128/AEM.68.8.3925-3931.2002.

[6] M.B.V. Jensen, L.E. Horsfall, C. Wardrope, P.D. Togneri, J. Marles-Wright, S. J. Rosser, Characterisation of a new family of carboxyl esterases with an OsmC domain, PLoS One (2016), https://doi.org/10.1371/journal.pone.0166128.

[7] D. Guerrand, Lipases industrial applications: focus on food and agroindustries. OCL - Oilseeds Fats, Crop. Lipids, 2017, https://doi.org/10.1051/ocl/2017031.

[8] A. Gricajeva, I. Bikutè, L. Kalèdienè, Atypical organic-solvent tolerant bacterial hormone sensitive lipase-like homologue EstAG1 from Staphylococcus saprophyticus AG1: synthesis and characterization, Int. J. Biol. Macromol. (2019), https://doi.org/10.1016/j.ijbiomac.2019.02.110.

[9] M.K. Singh, S. Shivakumaraswamy, S.N. Gummadi, N. Manoj, Role of an Nterminal extension in stability and catalytic activity of a hyperthermostable $\alpha / \beta$ hydrolase fold esterase, Protein Eng. Des. Sel. 30 (2016) 559-570, https://doi.org/ 10.1093/protein/gzx049.

[10] Y.Y. Huo, Z. Rong, S.L. Jian, C. Di Xu, J. Li, X.W. Xu, A novel halotolerant thermoalkaliphilic esterase from marine bacterium Erythrobacter seohaensis SW135, Front. Microbiol. 8 (2017) 1-11, https://doi.org/10.3389/fmicb.2017.02315.

[11] R. Ranjan, M.K. Yadav, G. Suneja, R. Sharma, Discovery of a diverse set of esterases from hot spring microbial mat and sea sediment metagenomes, Int. J. Biol. Macromol. 119 (2018) 572-581, https://doi.org/10.1016/j.ijbiomac. 2018.07.170.

[12] Y. Wang, Y. Xu, Y. Zhang, A. Sun, Y. Hu, Utilization of deep-sea microbial esterase PHE21 to generate chiral sec-butyl acetate through kinetic resolutions, Chirality 30 (2018) 1027-1035, https://doi.org/10.1002/chir.22983.

[13] J. Zheng, J. Wang, S. Zhou, X. Li, X. Ying, Z. Wang, Protein expression and purifi cation A stereoselective esterase from Bacillus megaterium: puri fi cation, gene cloning, expression and catalytic properties, Protein Expr. Purif. 136 (2017) 66-72, https://doi.org/10.1016/j.pep.2015.10.001.

[14] A. Casaburi, F. Villani, F. Toldrá, Y. Sanz, Protease and esterase activity of staphylococci, Int. J. Food Microbiol. 112 (2006) 223-229, https://doi.org/ 10.1016/j.ijfoodmicro.2006.04.008.

[15] B. Kannoju, S. Ganapathiwar, H. Nunavath, B. Sunkar, B. Bhukya, Plausible exploitation of Jatropha de-oiled seed cake for lipase and phytase production and simultaneous detoxification by Candida parapsilosis isolated from poultry garbage, Bioresour. Technol. (2017), https://doi.org/10.1016/j.biortech.2016.11.065.

[16] H. Zhang, Y. Xia, M. Zhou, J. Zheng, Z. Wang, Y. Zhang, Purification and characterization of a thermoalkaliphilic esterase from Bacillus cereus WZZ006 for enantioselective resolution of indoxacarb intermediate, Int. J. Biol. Macromol. 140 (2019) 358-367, https://doi.org/10.1016/j.ijbiomac.2019.08.140.
[17] P. Gao, Q. Jiang, Y. Xu, W. Xia, Esterase activities of autochthonous starter cultures to increase volatile flavour compounds in Chinese traditional fermented fish (Suan yu), Int. J. Food Prop. (2017), https://doi.org/10.1080/10942912.2017.1306556.

[18] G. Oleas, E. Callegari, R. Sepúlveda, J. Eyzaguirre, Heterologous expression, purification and characterization of three novel esterases secreted by the lignocellulolytic fungus Penicillium purpurogenum when grown on sugar beet pulp, Carbohydr. Res. (2017), https://doi.org/10.1016/j.carres.2017.03.014.

[19] N. Curci, A. Strazzulli, F. De Lise, R. Iacono, L. Maurelli, F. Dal Piaz, B. CobucciPonzano, M. Moracci, Identification of a novel esterase from the thermophilic bacterium Geobacillus thermodenitrificans NG80-2, Extremophiles (2019), https://doi.org/10.1007/s00792-019-01093-9.

[20] N.H.F. Hashim, N.M. Mahadi, R.M. Illias, S.R. Feroz, F.D. Abu Bakar, A.M. A. Murad, Biochemical and structural characterization of a novel cold-active esterase-like protein from the psychrophilic yeast Glaciozyma antarctica, Extremophiles 22 (2018) 607-616, https://doi.org/10.1007/s00792-018-1021-z.

[21] R.S. Singh, N. Kaur, V. Rana, J.F. Kennedy, Pullulan: A novel molecule for biomedical applications, Carbohydr. Polym. (2017), https://doi.org/10.1016/j. carbpol.2017.04.089.

[22] D.P. Meneses, E.J. Gudiña, F. Fernandes, L.R.B. Gonçalves, L.R. Rodrigues, S. Rodrigues, The yeast-like fungus Aureobasidium thailandense LB01 produces a new biosurfactant using olive oil mill wastewater as an inducer, Microbiol. Res. 204 (2017) 40-47, https://doi.org/10.1016/j.micres.2017.07.004.

[23] E.A. Elsayed, M.A. Farid, H.A. El-Enshasy, Enhanced Natamycin production by Streptomyces natalensis in shake-flasks and stirred tank bioreactor under batch and fed-batch conditions, BMC Biotechnol. 19 (2019) 46, https://doi.org/10.1186/ s12896-019-0546-2.

[24] J.M. Robert, F.S. Lattari, A.C. Machado, A.M. de Castro, R.V. Almeida, F.A. G. Torres, F. Valero, D.M.G. Freire, Production of recombinant lipase B from Candida antarctica in Pichia pastoris under control of the promoter PGK using crude glycerol from biodiesel production as carbon source, Biochem. Eng. J. (2017), https://doi.org/10.1016/j.bej.2016.11.018.

[25] K.P. Acharya, P. Shilpkar, M.C. Shah, Optimization study of esterase production by monocrotophos degrading Bacterium Bacillus subtilis KPA-1, J. Pure Appl. Microbiol. 10 (2016) 2079-2087.

[26] C.A. Mazzucotelli, R. Moreira, R. Ansorena, Statistical optimization of medium components and physicochemical parameters to simultaneously enhance bacterial growth and esterase production by Bacillus thuringiensis, Can. J. Microbiol. 34 (2016) 24-34.

[27] L.J. Rincón, B. Agualimpia, G. Zafra, Differential protein profiles of the lipolytic yeast candida palmioleophila under different growth conditions, Chem. Eng. Trans. (2018), https://doi.org/10.3303/CET1864058.

[28] S. Magdouli, T. Guedri, R. Tarek, S.K. Brar, J.F. Blais, Bioresource Technology Valorization of raw glycerol and crustacean waste into value added products by Yarrowia lipolytica, Bioresour. Technol. 243 (2017) 57-68, https://doi.org/ 10.1016/j.biortech.2017.06.074.

[29] M. Turk, C. Gostinčar, Glycerol metabolism genes in Aureobasidium pullulans and Aureobasidium subglaciale, Fungal Biol. 122 (2018) 63-73, https://doi.org/ 10.1016/j.funbio.2017.10.005.

[30] S. Kowalczyk, E. Komoń-Janczara, A. Glibowska, A. Kuzdraliński, T. Czernecki, Z. Targoński, A co-utilization strategy to consume glycerol and monosaccharide by Rhizopus strains for fumaric acid production, AMB Express (2018), https://doi. org/10.1186/s13568-018-0601-8.

[31] J.M. Cruz, C. Hughes, B. Quilty, R.N. Montagnolli, E.D. Bidoia, Agricultural Feedstock Supplemented With Manganese for Biosurfactant Production by Bacillus subtilis, Waste and Biomass Valorization, 2018, https://doi.org/10.1007/s12649017-0019-6.

[32] M.J. Rahimi, H. Sitaraman, D. Humbird, J.J. Stickel, Computational fluid dynamics study of full-scale aerobic bioreactors: evaluation of gas-liquid mass transfer, oxygen uptake, and dynamic oxygen distribution, Chem. Eng. Res. Des. 139 (2018) 283-295, https://doi.org/10.1016/j.cherd.2018.08.033.

[33] D.N.X. Salmon, R.C. Fendrich, M.A. Cruz, V.W. Montibeller, L.P.S. Vandenberghe, C.R. Soccol, M.R. Spier, Bioprocess for phytase production by Ganoderma sp. MR56 in different types of bioreactors through submerged cultivation, Biochem. Eng. J. (2016), https://doi.org/10.1016/j.bej.2016.07.015.

[34] D. Dasgupta, T. Sharma, A. Bhatt, S. Bandhu, D. Ghosh, Cultivation of oleaginous yeast Rhodotorula mucilaginosa IIPL32 in split column airlift reactor and its influence on fuel properties, Biocatal. Agric. Biotechnol. (2017), https://doi.org/ 10.1016/j.bcab.2017.04.002.

[35] M. Dubois, K. a Gilles, J.K.H. Ton, P. a Rebers, F. Smith, Colorimetric method for determination of sugars and related substances, Anal. Chem. 28 (1956) 350-356, https://doi.org/10.1021/ac60111a017.

[36] O.H. Lowry, N.J. Rosebrough, A.L. Farr, R.J. Randall, Protein measurement with the folin phenol reagent, J. Biol. Chem. 193 (1951) 265-275.

[37] N. Gomes, C. Gonc, Analytical Methods Optimization of a Colorimetric Assay for Yeast Lipase Activity in Complex, 2011, pp. 0-5, https://doi.org/10.1039/ c0ay00680g.

[38] A.C. Lemes, S.C. Silvério, S. Rodrigues, L.R. Rodrigues, Integrated strategy for purification of esterase from Aureobasidium pullulans, Sep. Purif. Technol. 209 (2019) 409-418, https://doi.org/10.1016/j.seppur.2018.07.062.

[39] M.M. Bradford, A rapid and sensitive method for the quantitation microgram quantities of protein utilizing the principle of protein-dye binding, Anal. Biochem. 254 (1976) 248-254.

[40] U.K. LAEMMLI, Cleavage of structural proteins during the assembly of the head of bacteriophage T4, Nature 227 (1970) 680-685, https://doi.org/10.1038/ $227680 a 0$. 
[41] R. Singh, N. Gupta, V.K. Goswami, R. Gupta, A simple activity staining protocol for lipases and esterases, Appl. Microbiol. Biotechnol. 70 (2006) 679-682, https://doi. org/10.1007/s00253-005-0138-z.

[42] Y. Guo, X. Yu, Y. Xu, Cloning, expression and characterization of two thermostable esterases from Aquifex aeolicus VF5, J. Mol. Catal., B Enzym. (2017) 1-10, https:// doi.org/10.1016/J.MOLCATB.2017.01.008.

[43] D.L.H. Maia, F.A.N. Fernandes, Effects of operating conditions on the copolymerization of Castor oil maleate-Styrene by suspension polymerization, Macromol. React. Eng. (2019), https://doi.org/10.1002/mren.201900017.

[44] M. Suryia Prabha, K. Divakar, J. Deepa Arul Priya, G. Panneer Selvam, N. Balasubramanian, P. Gautam, Statistical analysis of production of protease and esterase by a newly isolated Lysinibacillus fusiformis AU01: purification and application of protease in sub-culturing cell lines, Ann. Microbiol. 65 (2015) 33-46, https://doi.org/10.1007/s13213-014-0833-z.

[45] D.F.M. Turati, A.F. Almeida, C.C. Terrone, J.M.F. Nascimento, C.R.F. Terrasan, G. Fernandez-Lorente, B.C. Pessela, J.M. Guisan, E.C. Carmona, Thermotolerant lipase from Penicillium sp. Section Gracilenta CBMAI 1583: effect of carbon sources on enzyme production, biochemical properties of crude and purified enzyme and substrate specificity, Biocatal. Agric. Biotechnol. (2019), https://doi. org/10.1016/j.bcab.2018.10.002.

[46] W.G. De Morais, E.S. Kamimura, E.J. Ribeiro, B.C. Pessela, V.L. Cardoso, M.M. De Resende, Optimization of the production and characterization of lipase from Candida rugosa and Geotrichum candidum in soybean molasses by submerged fermentation, Protein Expr. Purif. 123 (2016) 26-34, https://doi.org/10.1016/j. pep.2016.04.001.

[47] T.L.R. Corrêa, M.P. Zubieta, J. a Teixeira, M. V de Queiroz, E.F. de Araújo, Carboxyl ester hydrolase from Penicillium expansum: cloning, characterization and overproduction by Penicillium griseoroseum, J. Appl. Microbiol. 115 (2013) 114-124, https://doi.org/10.1111/jam.12215.

[48] E.L. Regner, H.N. Salvatierra, M.D. Baigorí, L.M. Pera, Biomass-bound biocatalysts for biodiesel production: tuning a lipolytic activity from Aspergillus niger MYA 135 by submerged fermentation using agro-industrial raw materials and waste products, Biomass Bioenergy 120 (2019) 59-67, https://doi.org/10.1016/j. biombioe.2018.11.005.

[49] F.F. Castro, A.B.P. Pinheiro, E.C.M. Gerhardt, Production, Purification, and Characterization of a Novel Serine-esterase From Aspergillus westerdijkiae, 2018, pp. 131-143, https://doi.org/10.1002/jobm.201700509.

[50] J. Hemmerich, N. Adelantado, J.M. Barrigón, X. Ponte, A. Hörmann, P. Ferrer, F. Kensy, F. Valero, Comprehensive clone screening and evaluation of fed-batch strategies in a microbioreactor and lab scale stirred tank bioreactor system: application on Pichia pastoris producing Rhizopus oryzae lipase, Microb. Cell Fact. (2014), https://doi.org/10.1186/1475-2859-13-36.

[51] S.S. de Jesus, J. Moreira Neto, R. Maciel Filho, Hydrodynamics and mass transfer in bubble column, conventional airlift, stirred airlift and stirred tank bioreactors, using viscous fluid: a comparative study, Biochem. Eng. J. (2017), https://doi.org/ 10.1016/j.bej.2016.11.019.

[52] J.F. de, M. Burkert, R.R. Maldonado, F. Maugeri Filho, M.I. Rodrigues, Comparison of lipase production by Geotrichum candidum in stirring and airlift fermenters, J. Chem. Technol. Biotechnol. (2005), https://doi.org/10.1002/jctb.1157.

[53] E.A.R. Rosa, L.F. Bianchini, R.C.P. da Silva Ramos, A.B. Arantes, R.F. da Silva, J. Glassey, Hydrodynamics of split-rectangle-internal loop airlift bioreactor with variations in riser and downcomer cross-sectional areas based on the golden ratio, J. Chem. Technol. Biotechnol. (2019), https://doi.org/10.1002/jctb.5890.

[54] C. Chen, Z. Chi, G. Liu, H. Jiang, Z. Hu, Z. Chi, Production, purification, characterization and gene cloning of an esterase produced by Aureobasidium melanogenum HN6. 2, Process Biochem. 53 (2017) 69-79, https://doi.org/ 10.1016/j.procbio.2016.12.006.

[55] S. Pradeep, M.S. Josh, E.S. Hareesh, S. Kumar, S. Benjamin, Achromobacter denitrificans strain SP1 produces an intracellular esterase upon utilizing di (2ethylhexyl)phthalate, Int. Biodeterior. Biodegrad. 105 (2015) 160-167, https:// doi.org/10.1016/j.ibiod.2015.09.007.

[56] Z.H. Luo, J.F. Ding, W. Xu, T.L. Zheng, T.H. Zhong, Purification and characterization of an intracellular esterase from a marine Fusarium fungal species showing phthalate diesterase activity, Int. Biodeterior. Biodegrad. 97 (2015) 7-12, https://doi.org/10.1016/j.ibiod.2014.10.006.

[57] K. Divakar, M. Suryia Prabha, G. Pennathur, Purification, immobilization and kinetic characterization of G-X-S-x-G esterase with short chain fatty acid specificity from Lysinibacillus fusiformis AU01, Biocatal. Agric. Biotechnol. 12 (2017) 131-141, https://doi.org/10.1016/j.bcab.2017.09.007.

[58] C.W. Lee, S. Kwon, S.H. Park, B.Y. Kim, W. Yoo, B.H. Ryu, H.W. Kim, S.C. Shin, S. Kim, H. Park, T.D. Kim, J.H. Lee, Crystal structure and functional characterization of an esterase (EaEST) from exiguobacterium antarcticum, PLoS One 12 (2017) 1-19, https://doi.org/10.1371/journal.pone.0169540.

[59] J. Dong, M.A.A. Gasmalla, W. Zhao, J. Sun, W. Liu, M. Wang, L. Han, R. Yang, Characterization of a cold-adapted esterase and mutants from a psychotolerant Pseudomonas sp. Strain, Biotechnol. Appl. Biochem. 64 (2017) 686-699, https:// doi.org/10.1002/bab.1525.

[60] W. Li, H. Shi, H. Ding, L. Wang, Y. Zhang, X. Li, Protein Expression and Puri fi cation Characterization of two novel thermostable esterases from Thermoanaerobacterium thermosaccharolyticum, Protein Expr. Purif. 152 (2018) 64-70, https://doi.org/10.1016/j.pep.2018.04.010.

[61] B. Ozcan, G. Ozyilmaz, C. Cokmus, M. Caliskan, Characterization of extracellular esterase and lipase activities from five halophilic archaeal strains, J. Ind. Microbiol. Biotechnol. 36 (2009) 105-110, https://doi.org/10.1007/s10295-008-0477-8.

[62] D.M. Kambiranda, S.M. Asraful-Islam, K.M. Cho, R.K. Math, Y.H. Lee, H. Kim, H. D. Yun, Expression of esterase gene in yeast for organophosphates biodegradation, Pestic. Biochem. Physiol. 94 (2009) 15-20, https://doi.org/10.1016/j. pestbp.2009.02.006.

[63] D. Alex, A. Shainu, A. Pandey, R.K. Sukumaran, Esterase Active in Polar Organic Solvents from the YeastPseudozyma sp. NII 08165, Enzyme Res. 2014 (2014) 494682, https://doi.org/10.1155/2014/494682.

[64] A. Saika, H. Koike, T. Yarimizu, T. Watanabe, H. Kitamoto, T. Morita, Deficiency of biodegradable plastic-degrading enzyme production in a gene-deletion mutant of phyllosphere yeast, Pseudozyma antarctica defective in mannosylerythritol lipid biosynthesis, AMB Express (2019), https://doi.org/10.1186/s13568-019-0825-2.

[65] Y. Yang, P. Li, J. Jiao, Z. Yang, M. Lv, Y. Li, C. Zhou, C. Wang, Z. He, Y. Liu, S. Song, Renewable sourced biodegradable mulches and their environment impact, Sci. Hortic. (Amst.) 268 (2020) 109375, https://doi.org/10.1016/j. scienta.2020.109375.

[66] A. Magnin, E. Pollet, R. Perrin, C. Ullmann, C. Persillon, V. Phalip, L. Avérous, Enzymatic recycling of thermoplastic polyurethanes: synergistic effect of an esterase and an amidase and recovery of building blocks, Waste Manag. 85 (2019) 141-150, https://doi.org/10.1016/j.wasman.2018.12.024. 